\title{
Economic Diversification and Sustainable Development of GCC Countries
}

\author{
Joerg Beutel
}

\section{INTRODUCTION}

For decades now, exports and imports of most countries have been growing more rapidly than domestic production. This is a strong indication that, besides foreign trade in final products, trade in intermediates is also becoming increasingly important. Globalisation in production is changing the way in which nations interact, and any analysis of diversification should therefore also encompass the worldwide exchange of intermediates in production. For this reason, an input-output approach, which accounts for the role of intermediates, is more appropriate for any analysis of diversification than a traditional approach based purely on macroeconomic data.

This chapter analyses economic diversification in the GCC using data from input-output tables to compare the performance of these economies with that of a 'reference case', Norway, which is considered as having successfully diversified its economy despite having a large oil resource

\footnotetext{
J. Beutel $(\bowtie)$

Konstanz University of Applied Sciences, Konstanz, Germany e-mail: Joerg.Beutel@htwg-konstanz.de

(C) The Author(s) 2021 https://doi.org/10.1007/978-981-15-5728-6_6
} 
base. It also assesses their relative progress on sustainable development using a new measure, adjusted net savings, which measures the 'true' rate of savings in an economy after accounting for investments in manmade and human capital, depletion of natural resources and damage from environmental pollution. This view of sustainable development requires that the nation passes on an aggregate stock of physical capital, human capital and natural capital to the next generation that is not smaller than the one that currently exists. This requires that the loss of depleting resources be offset by increasing the stock of physical and human capital.

The article concludes that GCC countries have (contrary to expectation) collectively performed relatively well on diversification, but their performance on sustainable development varies between countries.

The required information for sustainable development and diversification can be deducted from the national accounts in great detail. The main sources for analysis are monetary and physical supply and use tables, sector accounts, extended input-output tables and social accounting matrices.

\section{Trends in Production and Foreign Trade}

Since the foundation of the World Trade Organization (WTO) in 1995, trade boosted thanks to reduced barriers. Since then, exports and imports of most countries have been growing more rapidly than domestic production. Globalisation in production is changing the way in which nations interact, and any analysis of diversification should therefore also encompass the worldwide exchange of intermediates in production. This is the main reason why we promote an input-output approach for the analysis of diversification and sustainable development (Beutel 2012).

\subsection{Exports and Imports}

If exports and imports are growing faster than GDP, the shares of exports and imports in GDP are also increasing. Furthermore, if net exports grow faster than GDP, the purchasing power of the nation is increasing and imports also tend to grow faster than GDP. In Table 6.1, GDP and foreign 


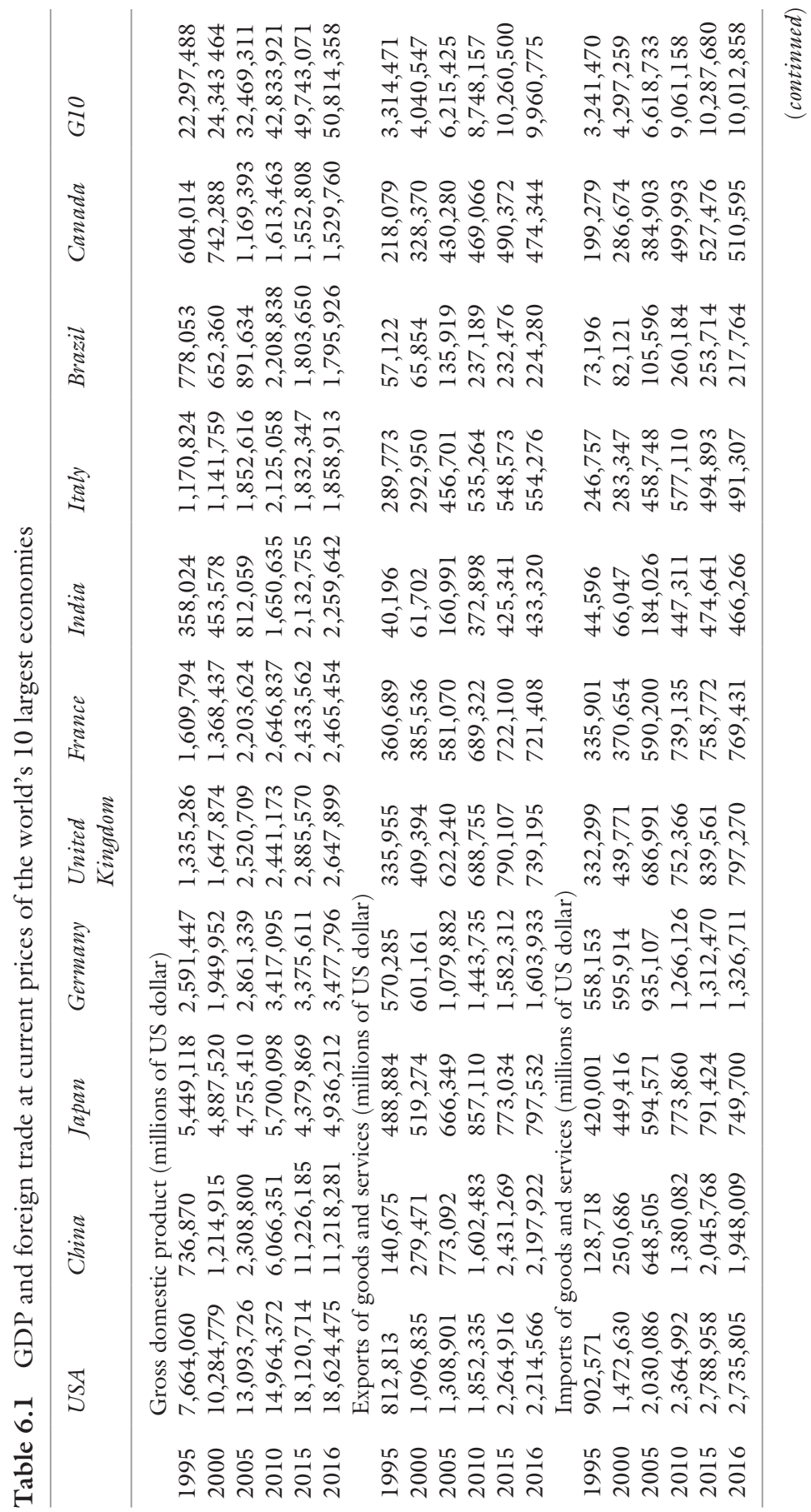




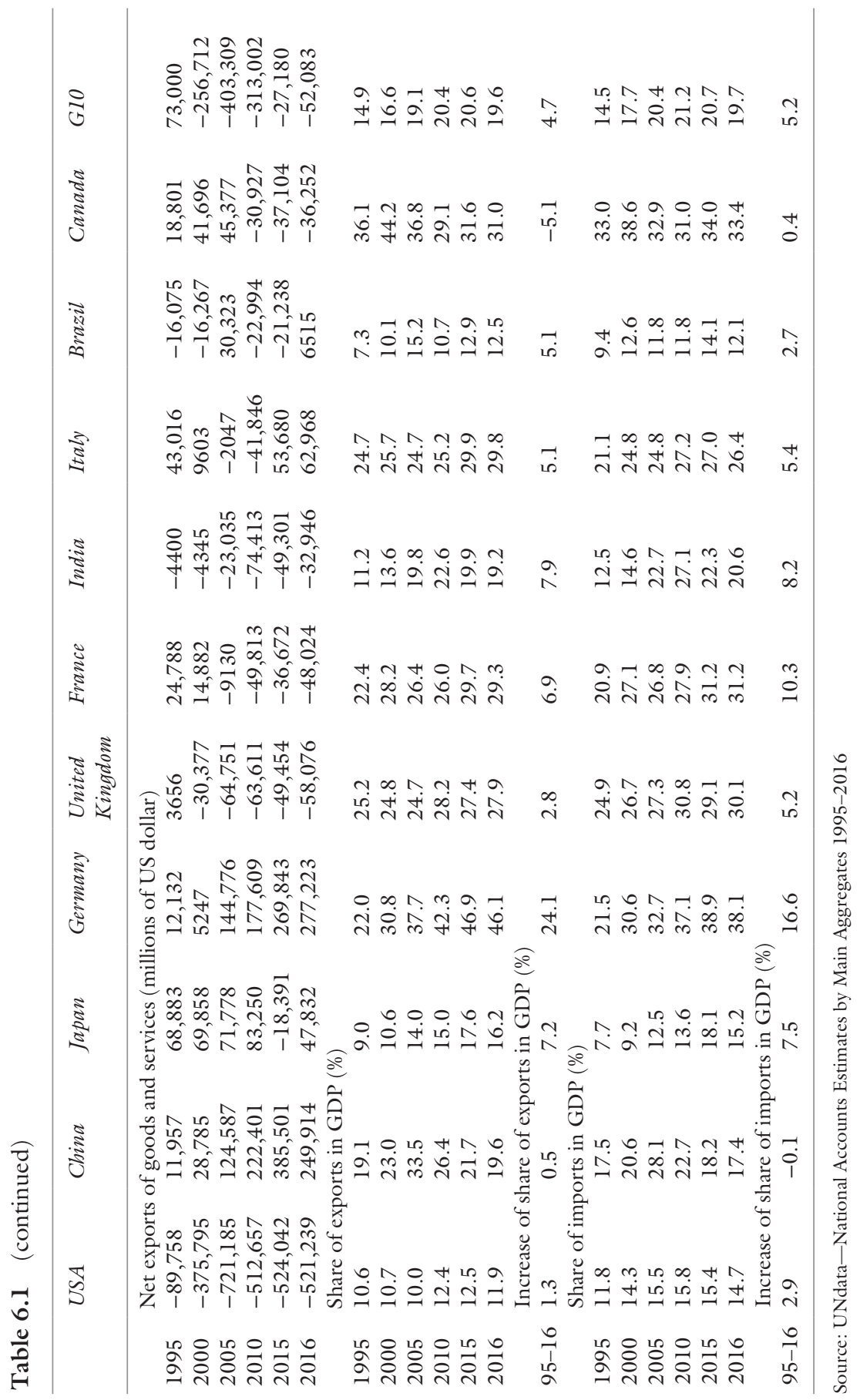


trade are shown for the 10 largest economies of the world (G10) for the last two decades. The most striking examples of an increase in the share of exports in GDP between 1995 and 2016 are Germany (+24.1 per cent), India $(+7.9$ per cent), Japan $(+7.2$ per cent $)$, France $(+6.9$ per cent $)$, Italy $(+5.1$ per cent $)$ and Brazil $(+5.1$ per cent $)$.

Substantial increases in the share of imports in GDP during the period 1995-2016 are observed for Germany $(+16.6$ per cent), France $(+10.3$ percent $)$, India $(+8.2$ per cent $)$, Japan $(+7.5$ per cent $)$ and Italy $(+5.4$ per cent). For the 10 largest economies combined (G10) the increase of the export share in GDP during the period 1995-2016 was +4.7 per cent and of the import share in GDP +5.2 per cent.

In Table 6.2, the same information on GDP, exports and imports was collected for the GCC countries. If net exports of a nation grow more rapidly than GDP, the purchasing power of the nation is increasing. In consequence, imports tend also to grow more than GDP. In the GCC countries, the share of exports in GDP increased by 12.9 per cent during the period 1995-2016, while the corresponding share of imports in GDP increased by 14.0 per cent. The most rapid increase of the export share was observed for the United Arab Emirates (UAE) (+57.9 per cent) and Oman (+14.0 per cent). Similar results were observed for the import share in GDP for UAE (+41.3 per cent) and Oman (+17.0 per cent).

\subsection{Intermediate Consumption, Value Added and Output}

The numbers in the table suggest that during the last 20 years, the globalisation of economic activities has caused increasing worldwide interdependencies in production, leading to the intermediate consumption of goods and services becoming a key element in the intensification of economic diversification. If the consumption of intermediate products is growing above its GDP growth rate, an economy is moving towards more complex participation in inter-industrial production.

For the future, the challenge for many countries is to become a successful member in the international chain of value added. As shown on Table 6.3, the share of intermediates in total output for G10 countries increased by 5.9 per cent in the period 1995-2011. As a consequence, the corresponding share of gross value added in output declined in the same period by 5.9 per cent. In other words, in this period, the production 
Table 6.2 GDP and foreign trade at current prices of GCC countries

\begin{tabular}{|c|c|c|c|c|c|c|c|}
\hline & Babrain & Kuwait & Oman & Qatar & $\begin{array}{l}\text { Saudi } \\
\text { Arabia }\end{array}$ & $\begin{array}{l}\text { United } \\
\text { Arab } \\
\text { Emirates }\end{array}$ & $G C C$ \\
\hline & \multicolumn{7}{|c|}{ Gross domestic product (millions of US dollar) } \\
\hline 1995 & 6787 & 26,554 & 13,650 & 8041 & 143,152 & 66,603 & 264,786 \\
\hline 2000 & 9063 & 37,718 & 19,450 & 17,548 & 189,515 & 105,701 & 378,994 \\
\hline 2005 & 15,969 & 80,798 & 31,082 & 43,998 & 328,461 & 182,978 & 683,286 \\
\hline 2010 & 25,713 & 115,416 & 58,641 & 123,627 & 528,207 & 289,787 & $1,141,392$ \\
\hline 2015 & 31,126 & 114,059 & 69,832 & 164,641 & 651,757 & 358,135 & $1,389,551$ \\
\hline \multirow[t]{2}{*}{2016} & 32,179 & 110,346 & 63,171 & 152,452 & 639,617 & 348,744 & $1,346,509$ \\
\hline & \multicolumn{7}{|c|}{ Exports of goods and services (millions of US dollar) } \\
\hline 1995 & 4798 & 14,234 & 4757 & 3613 & 53,450 & 30,591 & 111,442 \\
\hline 2000 & 7176 & 21,301 & 10,474 & 11,964 & 82,259 & 53,889 & 187,063 \\
\hline 2005 & 13,397 & 51,692 & 19,633 & 29,017 & 187,389 & 122,071 & 423,199 \\
\hline 2010 & 17,880 & 76,952 & 38,500 & 78,069 & 261,831 & 225,275 & 698,507 \\
\hline 2015 & 26,326 & 62,024 & 39,166 & 92,291 & 218,010 & 359,401 & 797,218 \\
\hline \multirow[t]{2}{*}{2016} & 23,782 & 55,530 & 30,845 & 72,397 & 195,169 & 362,069 & 739,793 \\
\hline & \multicolumn{7}{|c|}{ Imports of goods and services (millions of US dollar) } \\
\hline 1995 & 4122 & 11,409 & 4009 & 3526 & 39,659 & 24,663 & 87,388 \\
\hline 2000 & 5132 & 11,371 & 5054 & 3966 & 46,926 & 36,003 & 108,452 \\
\hline 2005 & 10,287 & 22,839 & 11,173 & 13,208 & 81,798 & 83,671 & 222,975 \\
\hline 2010 & 13,097 & 35,034 & 24,166 & 29,717 & 174,203 & 184,221 & 460,439 \\
\hline 2015 & 22,302 & 51,627 & 36,667 & 59,271 & 253,555 & 265,950 & 689,371 \\
\hline \multirow[t]{2}{*}{2016} & 21,088 & 51,922 & 29,301 & 63,475 & 194,169 & 273,274 & 633,230 \\
\hline & \multicolumn{7}{|c|}{ Net exports of goods and services (millions of US dollar) } \\
\hline 1995 & 675 & 2825 & 749 & 86 & 13,791 & 5928 & 24,054 \\
\hline 2000 & 2044 & 9930 & 5420 & 7998 & 35,333 & 17,886 & 78,611 \\
\hline 2005 & 3110 & 28,853 & 8460 & 15,809 & 105,592 & 38,400 & 200,224 \\
\hline 2010 & 4783 & 41,918 & 14,333 & 48,352 & 87,628 & 41,054 & 238,069 \\
\hline 2015 & 4024 & 10,397 & 2500 & 33,020 & $-35,544$ & 93,451 & 107,848 \\
\hline \multirow[t]{2}{*}{2016} & 2694 & 3608 & 1544 & 8922 & 1000 & 88,795 & 106,563 \\
\hline & \multicolumn{7}{|c|}{ Share of exports in GDP (\%) } \\
\hline 1995 & 70.7 & 53.6 & 34.9 & 44.9 & 37.3 & 45.9 & 42.1 \\
\hline 2000 & 79.2 & 56.5 & 53.9 & 68.2 & 43.4 & 51.0 & 49.4 \\
\hline 2005 & 83.9 & 64.0 & 63.2 & 66.0 & 57.1 & 66.7 & 61.9 \\
\hline 2010 & 69.5 & 66.7 & 65.7 & 63.1 & 49.6 & 77.7 & 61.2 \\
\hline 2015 & 84.6 & 54.4 & 56.1 & 56.1 & 33.4 & 100.4 & 57.4 \\
\hline \multirow[t]{2}{*}{2016} & 73.9 & 50.3 & 48.8 & 47.5 & 30.5 & 103.8 & 54.9 \\
\hline & \multicolumn{7}{|c|}{ Increase of share of exports in GDP (\%) } \\
\hline $95-16$ & 3.2 & -3.3 & 14.0 & 2.6 & -6.8 & 57.9 & 12.9 \\
\hline
\end{tabular}


Table 6.2 (continued)

\begin{tabular}{llllllll}
\hline Bahrain & Kuwait & Oman & Qatar & $\begin{array}{l}\text { Saudi } \\
\text { Arabia }\end{array}$ & $\begin{array}{l}\text { United } \\
\text { Arab } \\
\text { Emirates }\end{array}$ & GCC \\
\hline \multicolumn{7}{c}{ Share of imports in GDP (\%) } \\
1995 & 60.7 & 43.0 & 29.4 & 43.9 & 27.7 & 37.0 & 33.0 \\
2000 & 56.6 & 30.1 & 26.0 & 22.6 & 24.8 & 34.1 & 28.6 \\
2005 & 64.4 & 28.3 & 35.9 & 30.0 & 24.9 & 45.7 & 32.6 \\
2010 & 50.9 & 30.4 & 41.2 & 24.0 & 33.0 & 63.6 & 40.3 \\
2015 & 71.7 & 45.3 & 52.5 & 36.0 & 38.9 & 74.3 & 49.6 \\
2016 & 65.5 & 47.1 & 46.4 & 41.6 & 30.4 & 78.4 & 47.0 \\
$95-16$ & 4.8 & 4.1 & 17.0 & -2.2 & 2.7 & 41.3 & 14.0 \\
\hline
\end{tabular}

Source: UNdata—National Accounts Estimates by Main Aggregates 1995-2016

process of the 10 largest economies became more complex and more interdependent. It is worth noticing that the share of intermediates in total output in China increased by 6.7 per cent, while the share of intermediates in the USA slightly declined by -0.4 per cent.

For the GCC countries combined, the share of intermediates and gross value added in total output was more or less constant during the last 20 years (see Table 6.4). However, among individual countries, the performance has been mixed. While large increases of intermediates were reported for Bahrain $(+10.6$ per cent), Oman $(+7.7$ per cent), Kuwait $(+5.4$ per cent $)$ and the $\operatorname{UAE}(+4.5$ per cent $)$, these were offset by the decline of intermediates in Saudi Arabia ( -4.1 per cent).

\section{Economic Diversification of the GCC Countries IN INTERNATIONAL COMPARISON}

The sustainable development of nations involves economic, social and environmental changes. Within this process, diversification and structural change of production and demand are closely related to many areas of the economy and society. 


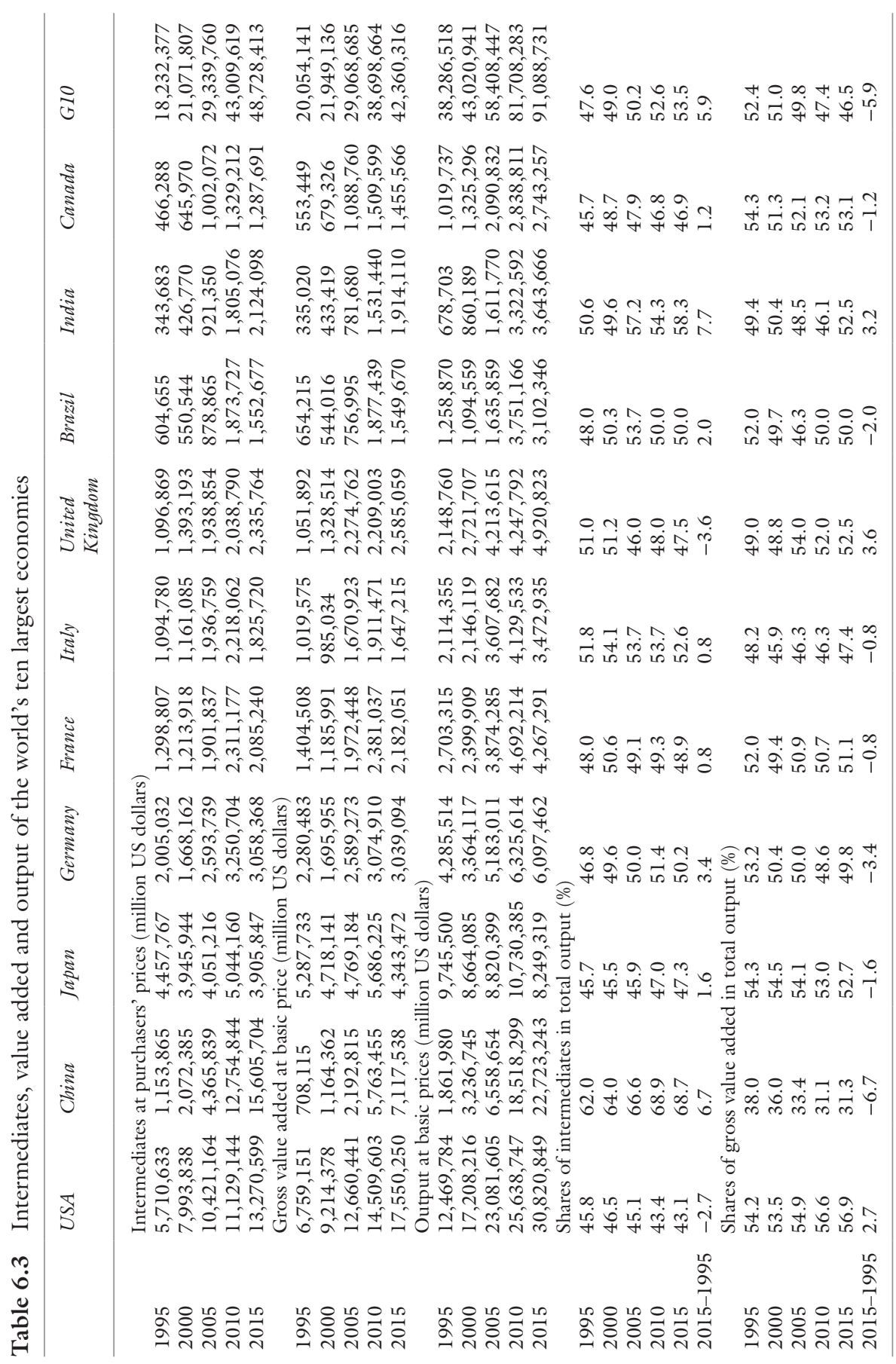


Table 6.4 Intermediates, value added and output at current prices of GCC countries

\begin{tabular}{|c|c|c|c|c|c|c|c|}
\hline & Babrain & Kuwait & Oman & Qatar & $\begin{array}{l}\text { Saudi } \\
\text { Arabia }\end{array}$ & $\begin{array}{l}\text { United } \\
\text { Arab } \\
\text { Emirates }\end{array}$ & $G C C$ \\
\hline & \multicolumn{7}{|c|}{ Intermediates at purchasers' prices (million US dollar) } \\
\hline 1995 & 3737 & 11,878 & 5131 & 3332 & 79,090 & 38,371 & 141,539 \\
\hline 2000 & 7101 & 16,019 & 7440 & 5351 & 99,219 & 64,268 & 199,398 \\
\hline 2005 & 14,009 & 43,685 & 13,197 & 14,670 & 164,159 & 117,210 & 366,929 \\
\hline 2010 & 24,374 & 79,339 & 29,639 & 55,329 & 262,678 & 194,448 & 645,807 \\
\hline \multirow{2}{*}{2015} & 26,396 & 74,149 & 39,613 & 68,906 & 307,508 & 252,409 & 768,981 \\
\hline & \multicolumn{7}{|c|}{ Gross value added at basic prices (million US dollar) } \\
\hline 1995 & 6782 & 26,879 & 13,685 & 8311 & 139,225 & 65 & 260,626 \\
\hline 2000 & 9063 & 39,015 & 19,326 & 18,052 & 184,162 & 104,337 & 373,955 \\
\hline 2005 & 15,969 & 83,808 & 31,784 & 44,053 & 319,210 & 180,617 & 675,441 \\
\hline 2010 & 25,442 & 131,065 & 59,876 & 124,080 & 512,817 & 289,880 & $1,143,160$ \\
\hline 2015 & 30,835 & 131,530 & 73,675 & 165,245 & 651,097 & 357,949 & $1,410,331$ \\
\hline \multicolumn{8}{|c|}{ Output at basic prices (million US dollar) } \\
\hline 1995 & 10,519 & 38,757 & 18,816 & 11,643 & 218,315 & 104,114 & 402,165 \\
\hline 2000 & 16,163 & 55,035 & 26,766 & 23,402 & 283,381 & 168,605 & 573,353 \\
\hline 2005 & 29,978 & 127,493 & 44,981 & 58,723 & 483,369 & 297,827 & $1,042,370$ \\
\hline 2010 & 49,816 & 210,403 & 89,515 & 179,410 & 775,494 & 484,328 & $1,788,966$ \\
\hline \multirow[t]{2}{*}{2015} & 57,231 & 205,679 & 113,288 & 234,151 & 958,604 & 610,358 & $2,179,312$ \\
\hline & \multicolumn{7}{|c|}{ Share of intermediates in output (\%) } \\
\hline 1995 & 35.5 & 30.6 & 27.3 & 28.6 & 36.2 & 36.9 & 35.2 \\
\hline 2000 & 43.9 & 29.1 & 27.8 & 22.9 & 35.0 & 38.1 & 34.8 \\
\hline 2005 & 46.7 & 34.3 & 29.3 & 25.0 & 34.0 & 39.4 & 35.2 \\
\hline 2010 & 48.9 & 37.7 & 33.1 & 30.8 & 33.9 & 40.1 & 36.1 \\
\hline \multirow[t]{2}{*}{2015} & 46.1 & 36.1 & 35.0 & 29.4 & 32.1 & 41.4 & 35.3 \\
\hline & \multicolumn{7}{|c|}{ Increase in share of intermediates in output $(\%)$} \\
\hline \multirow{2}{*}{$95-15$} & 10.6 & 5.4 & 7.7 & 0.8 & -4.1 & 4.5 & 0.1 \\
\hline & \multicolumn{7}{|c|}{ Share of gross value added in output (\%) } \\
\hline 1995 & 64.5 & 69.4 & 72.7 & 71.4 & 63.8 & 63.1 & 64.8 \\
\hline 2000 & 56.1 & 70.9 & 72.2 & 77.1 & 65.0 & 61.9 & 65.2 \\
\hline 2005 & 53.3 & 65.7 & 70.7 & 75.0 & 66.0 & 60.6 & 64.8 \\
\hline 2010 & 51.1 & 62.3 & 66.9 & 69.2 & 66.1 & 59.9 & 63.9 \\
\hline \multirow[t]{2}{*}{2015} & 53.9 & 63.9 & 65.0 & 70.6 & 67.9 & 58.6 & 64.7 \\
\hline & \multicolumn{7}{|c|}{ Increase in share of gross value added in output (\%) } \\
\hline $95-15$ & -10.6 & -5.4 & -7.7 & -0.8 & 4.1 & -4.5 & -0.1 \\
\hline
\end{tabular}

Source: UNdata-National Accounts Estimates by Main Aggregates 1995-2016; OECD 
For income per capita to converge, countries must move towards more diversified and complex production structures incorporating more advanced technology and knowledge. Economic diversification means the diversification of exports and domestic production away from extreme dependence on a single dominant industry or a few natural-resourcebased products, as well as towards increased complexity and quality of output.

In the following two tables, data on gross value added by industry and on GDP by type of expenditure are presented for the GCC countries in 2016 to discuss their different economic structure. In this comparison, Norway will act as the reference, as this country is highly developed in many ways, generating substantial oil and gas revenues and benefitting from a successful sovereign wealth fund. The Government Pension Fund Global, also known as Oil Fund, was established in 1990 to invest the surplus revenue of the Norwegian petroleum sector for the benefit of future generations. It has over US\$1 trillion in assets, including 1.3 per cent of global stocks and shares, making it the world's largest sovereign wealth fund.

Table 6.5 reveals that the industry structure of the UAE is similar to that of Norway. It is also striking to observe that the industry structure of Iran is similar to the structure of the GCC countries combined, except for agriculture.

If we compare the industry structure of the individual GCC countries, we observe that their structure is quite diverse. The share of mining and utilities in gross value added is much higher in Kuwait than in Bahrain. Manufacturing in Kuwait has a very low share in gross value added, but in Bahrain this share is more than three times larger.

The oil and gas dependency of Kuwait and Oman was still high in 2016. The sector 'Mining and utilities' accounted for 51.4 per cent of gross value added in Kuwait, 42.6 per cent in Oman and 26.9 per cent in the GCC countries combined. The oil and gas dependency of Norway is considerably lower (19.0 per cent). And yet, if we compare Norway and the GCC in terms of the expenditure side of GDP, we observe a similar structure. But it is obvious that Norway is more developed concerning 'Other activities', which include private business services and government services. 


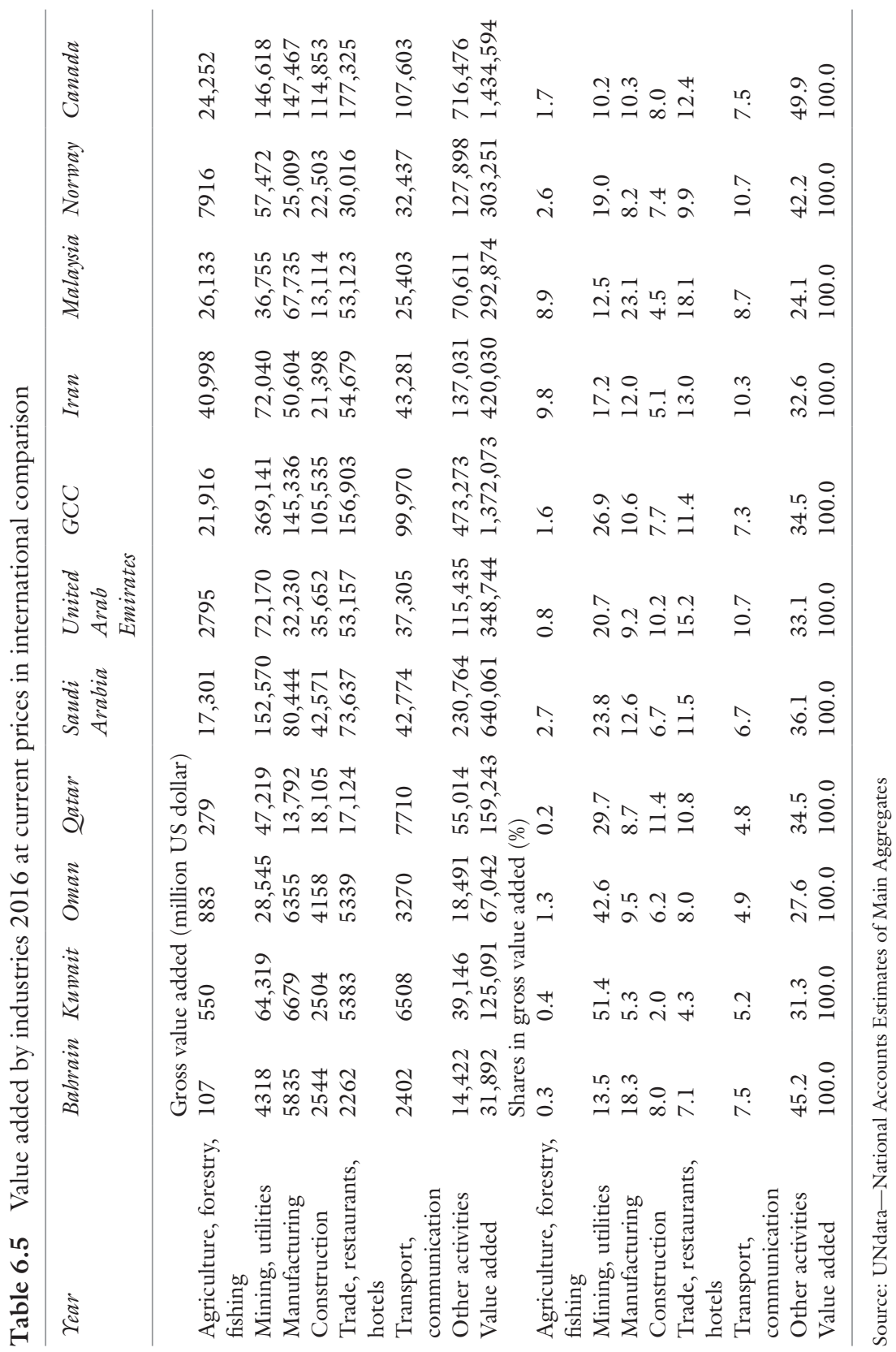


In Table 6.6, we present similar information for the expenditure side of GDP in 2016 for consumption, capital formation and foreign trade. Here, we observe significant differences between the GCC countries. The share of household consumption in GDP is similar in Norway (45.5 per cent), Bahrain (45.0 per cent), Kuwait (42.9 per cent) and Saudi Arabia (42.8 per cent). The share of government consumption is in the same range in Norway (24.3 per cent), Oman (28.2 per cent), Kuwait (27.7 per cent) and Saudi Arabia (25.8 per cent). By far the highest investment ratio is reported for Qatar (45.2 per cent) and for Oman (38.0 per cent). The shares of gross fixed capital formation in GDP in Norway (24.1 per cent) and in the GCC combined (23.6 per cent) are also similar.

In the bottom part of Table 6.6, we relate the results on the expenditure side of GDP to the population. The highest GDP per capita is reported for Norway $(70,617$ Mio \$/person), followed by the GCC countries Qatar (59.324 Mio \$/person), UAE (37,622 Mio \$/person) and Kuwait $(27,229$ Mio \$/person). But what matters for the well-being of the people is less GDP per capita than final consumption per capita. In this respect, among the selected countries, the gold medal goes to Norway (32,140 Mio \$/person), the silver medal to Canada (24,578 Mio \$/person) and the bronze medal to Qatar (15,312 Mio \$/person).

\subsection{Product Concentration and Product Diversification}

The most widely quoted product concentration and diversification indices are published by the United Nations Conference on Trade and Development (UNCTAD).

Figure 6.1 presents these indices for the GCC for the period 1995-2016. The product concentration index measures whether the exports and imports of the GCC are concentrated on a few products or distributed in a more homogeneous manner among a series of products. The diversification index indicates whether the structure of exports or imports by product differs in the GCC from the world pattern.

Both top two indices for GCC exports show a falling trend. The concentration index for exports indicates that today a broader range of products is exported than just oil and gas. The export diversification index shows that the divergence from the world pattern was significantly reduced.

The bottom two indices for imports are relatively stable. The concentration index shows that imports are rather homogenously distributed among many of products. The diversification index for imports shows very little divergence from the pattern of world trade (Box 6.1). 


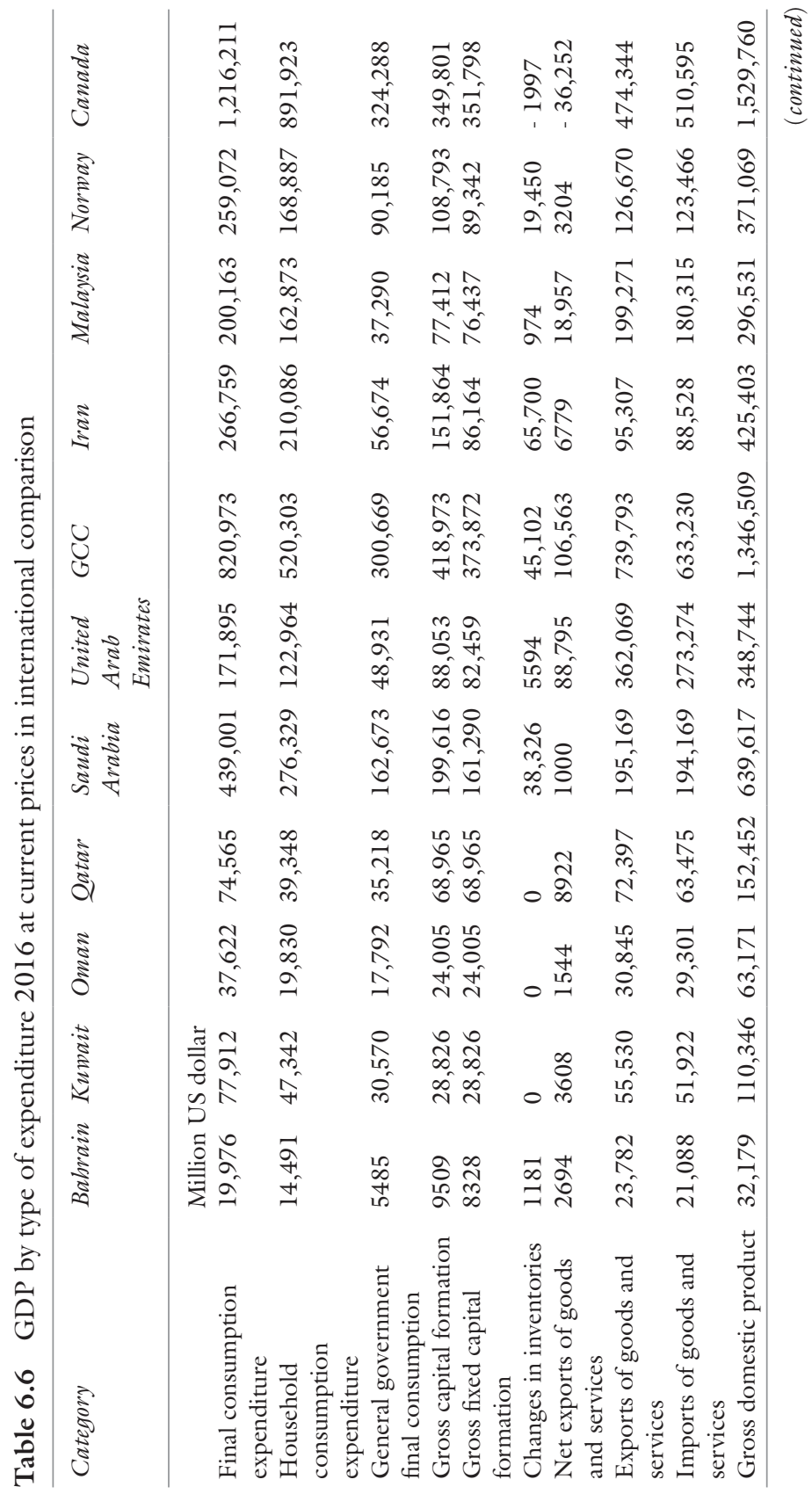




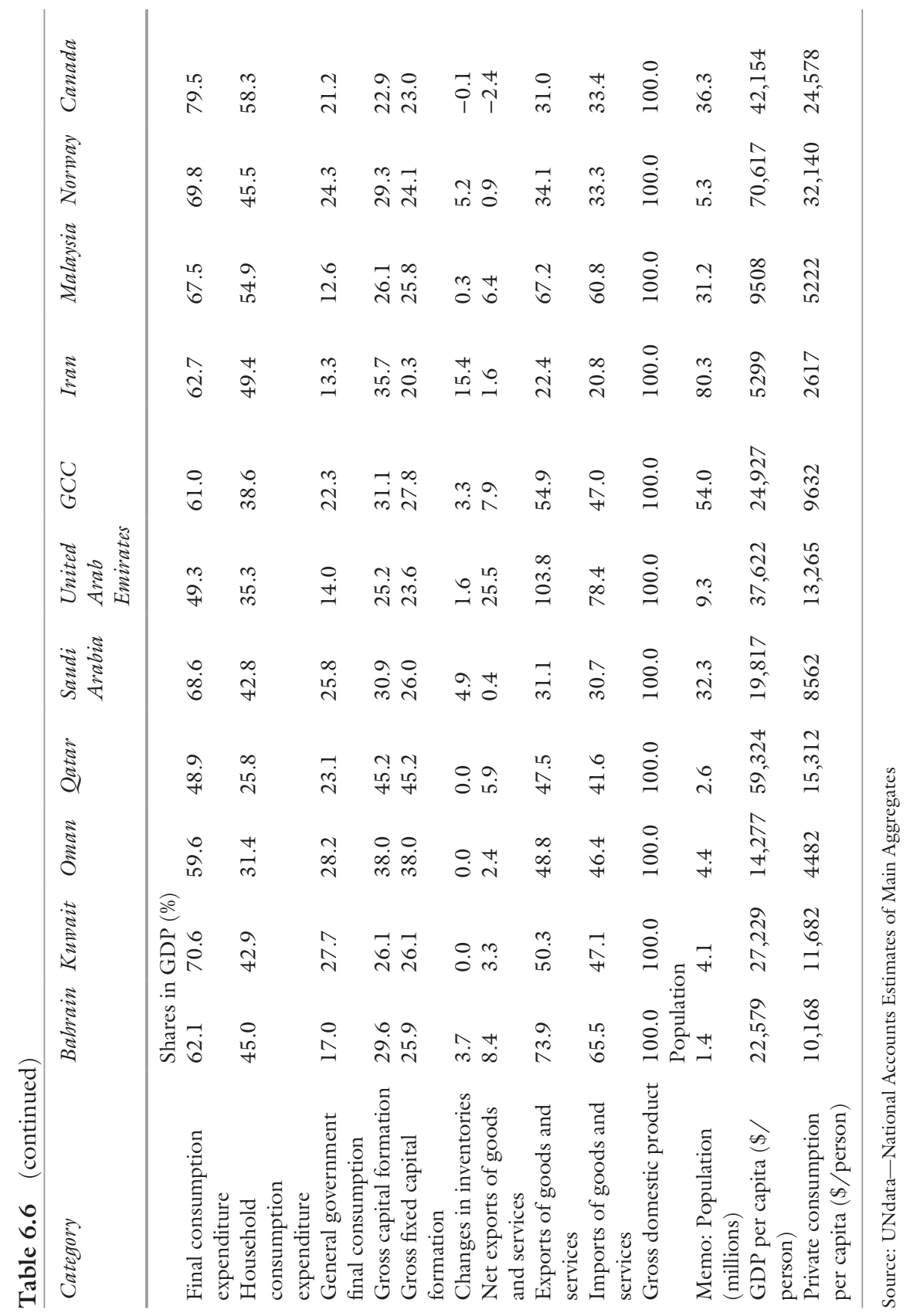




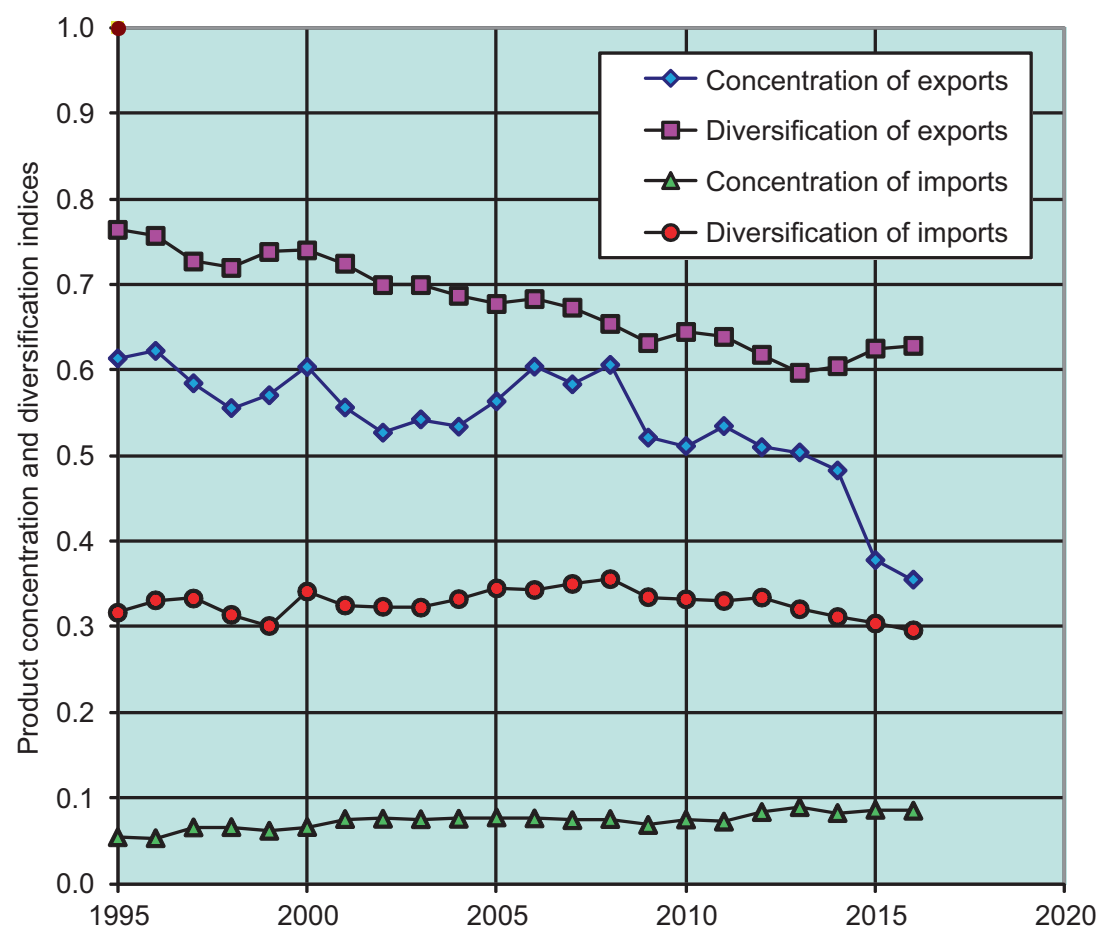

Fig. 6.1 Product concentration and diversification of exports and imports for GCC. (Source: UNCTADStat)

\subsection{Economic Diversification of the Industrial Sector}

The challenge is now to study the diversification of the industrial sector in the GCC countries. The key question is whether diversification has increased during the last 50 years.

The Herfindahl-Hirschman Index is the most widely used measure to evaluate market concentration and industry concentration of an economy. This time, the index is the sum of squared shares of the various industries in total gross value added. In the normalised form, the index varies from 0 to 1 .

In the case of a low value, the economy has a large number of industries with similar shares in gross value added, indicating high diversity. If the 
Box 6.1 Product Concentration and Diversification Indices of Exports and Imports

\section{Concentration Index:}

The concentration index, also named Herfindahl-Hirschman Index, is a measure of the degree of product concentration. The following normalised $\mathrm{HHI}$ is used in order to obtain values between 0 and 1 :

$$
H_{j}=\frac{\sqrt{\sum_{i=1}^{n}\left(\frac{x_{i j}}{X_{j}}\right)-\sqrt{\frac{1}{n}}}}{1-\sqrt{1 / n}}
$$

Where,

$\mathrm{Hj}=$ country or country group index

$\mathrm{xij}=$ value of export for country $\mathrm{j}$ and product $\mathrm{i}$

$\mathrm{Xj}=$ total exports of country $\mathrm{j}$

$$
X_{j}=\sum_{i=1}^{n} x_{i j}
$$

and

$\mathrm{n}=$ number of products (SITC Revision 3 at 3-digit group level).

An index value closer to 1 indicates a country's exports or imports are highly concentrated on a few products. On the contrary, values closer to 0 reflect exports or imports are more homogeneously distributed among a series of products.

\section{Diversification Index:}

The diversification index is computed by measuring the absolute deviation of the trade structure of a country from world structure:

$$
S_{j}=\frac{\sum_{i}\left|h_{i j}-h_{i}\right|}{2}
$$

Where,

hij $=$ share of product $\mathrm{i}$ in total exports or imports of country or country group $\mathrm{j}$

hi $=$ share of product $\mathrm{i}$ in total world exports or imports.

The diversification index takes values between 0 and 1 . A value closer to 1 indicates greater divergence from the world pattern.

Source: UNCTAD Merchandise: Product concentration and diversification indices of exports and imports, annual, 1995-2016 
index reaches 1 , only one industry accounts for all gross value added, and a high concentration of economic activity is given. Thus, a decline in the index signifies less concentration in the dominant industry or greater diversification. If more concentration in the dominant sector is observed, the indicator will be higher.

Figure 6.2 plots the Herfindahl-Hirschman Index for all GCC countries (Bahrain, Qatar, Kuwait, Oman, Saudi Arabia and UAE). The calculation is based on the UN Statistics Division's long time series for value added by economic activity for the period 1970-2016, covering the following seven industries: (1) agriculture, hunting, forestry and fishing, (2) mining and utilities, (3) manufacturing, (4) construction, (5) wholesale, retail trade, restaurants and hotels, $(6)$ transport, storage and communication and (7) other activities.

Starting from the first oil boom in 1974 and the second oil boom in 1978, the index steadily fell until 1998, indicating a successful process of diversification. However, at the end of the last century, the recovery of oil

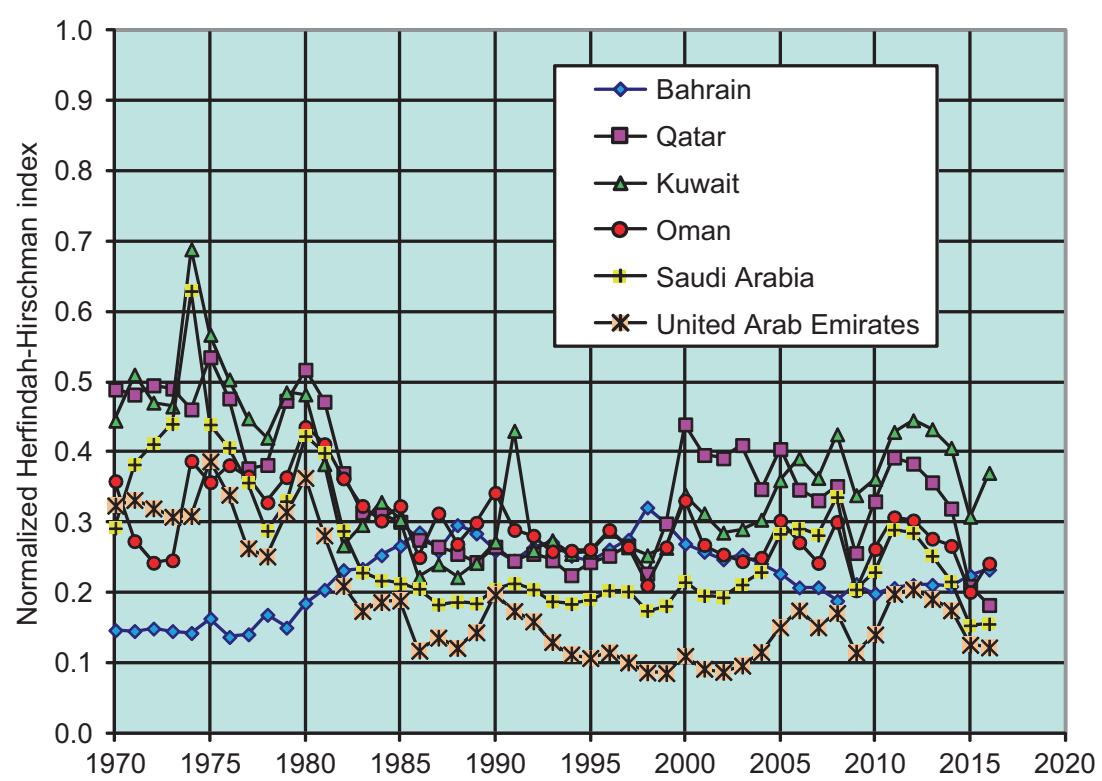

Fig. 6.2 Industry concentration index for the GCC countries. (Source: National Accounts Estimates of Main Aggregates-United Nations Statistics Division) 


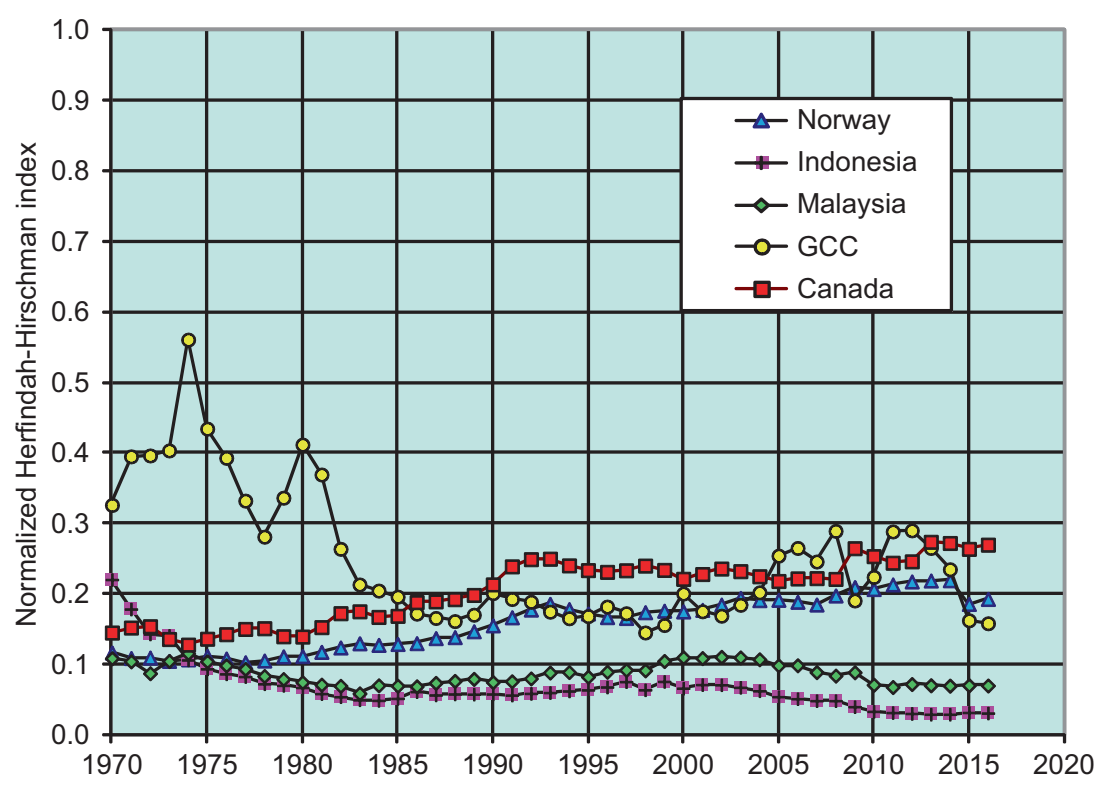

Fig. 6.3 Industry concentration index in international comparison. (Source: National Accounts Estimates of Main Aggregates-United Nations Statistics Division)

prices after a long period of relatively low prices seemingly provoked a reversal in the trend of industrial diversification in most GCC countries.

In Fig. 6.3, the Herfindal-Hirschman Index is presented for the GCC as an aggregate in comparison with selected reference countries. This figure clearly demonstrates that the GCC countries combined moved since 1995 in the concentration range of the reference countries Norway and Canada, while Malaysia and Iran manifested lower concentration.

\section{New Assessment for GCC Countries With InPuT-OUTput Data}

The best way of measuring the relationship between intermediate consumption, gross value added and final demand is through the use of inputoutput tables, which are derived from supply and use tables that are an integral part of National Accounts (Beutel 2017). 
The input-output table is a matrix containing detailed information on the production of goods and services in an economy. It details the intermediate and final uses of domestic and imported goods and services, and also covers net taxes on products and the gross value added of industries.

The required inputs and corresponding cost structures of industries and final demand categories (consumption, investment, exports) can be studied in the columns of the table, while the sales or output structure for goods and services and components of value added (compensation of employees, net taxes on production, consumption of fixed capital, net operating surplus) can be derived from the rows.

Extended input-output tables comprise other useful information derived from satellite systems which are integrated into the national accounts. The additional data include information in matrix form on investment and capital in values, while matrices on employment, energy, emissions, natural resources, waste, sewage and water show the corresponding quantities.

The extended input-output table of Saudi Arabia for 2010 in Table 6.7 has the following seven extensions with information in values and quantities:

1. Gross fixed capital formation (million Saudi riyals)

2. Capital stock (million Saudi riyals)

3. Employment (1000 persons)

4. Energy use (1000 tons of oil equivalent)

5. Air emissions (1000 tons)

6. Global warming, acid deposition, tropospheric ozone formation (1000 tons)

7. Water use (million cubic metres)

The first part of the extended input-output table in rows 1-18 comprises the traditional input-output table. In rows $1-8$, the use of domestic products in industries and final uses is shown. Imports and net taxes on products are presented in rows 10-11, followed by the various components of gross value added in rows 13-16. Detailed information on imported products is given in a separate import matrix below the inputoutput table in rows 19-27.

Environmentally extended input-output tables and models have become a powerful tool in supporting environmental and economic analyses and policies. They play an important role in providing the database for studying sustainable development and the impact of 
Table 6.7 Extended input-output table with satellite systems for Saudi Arabia

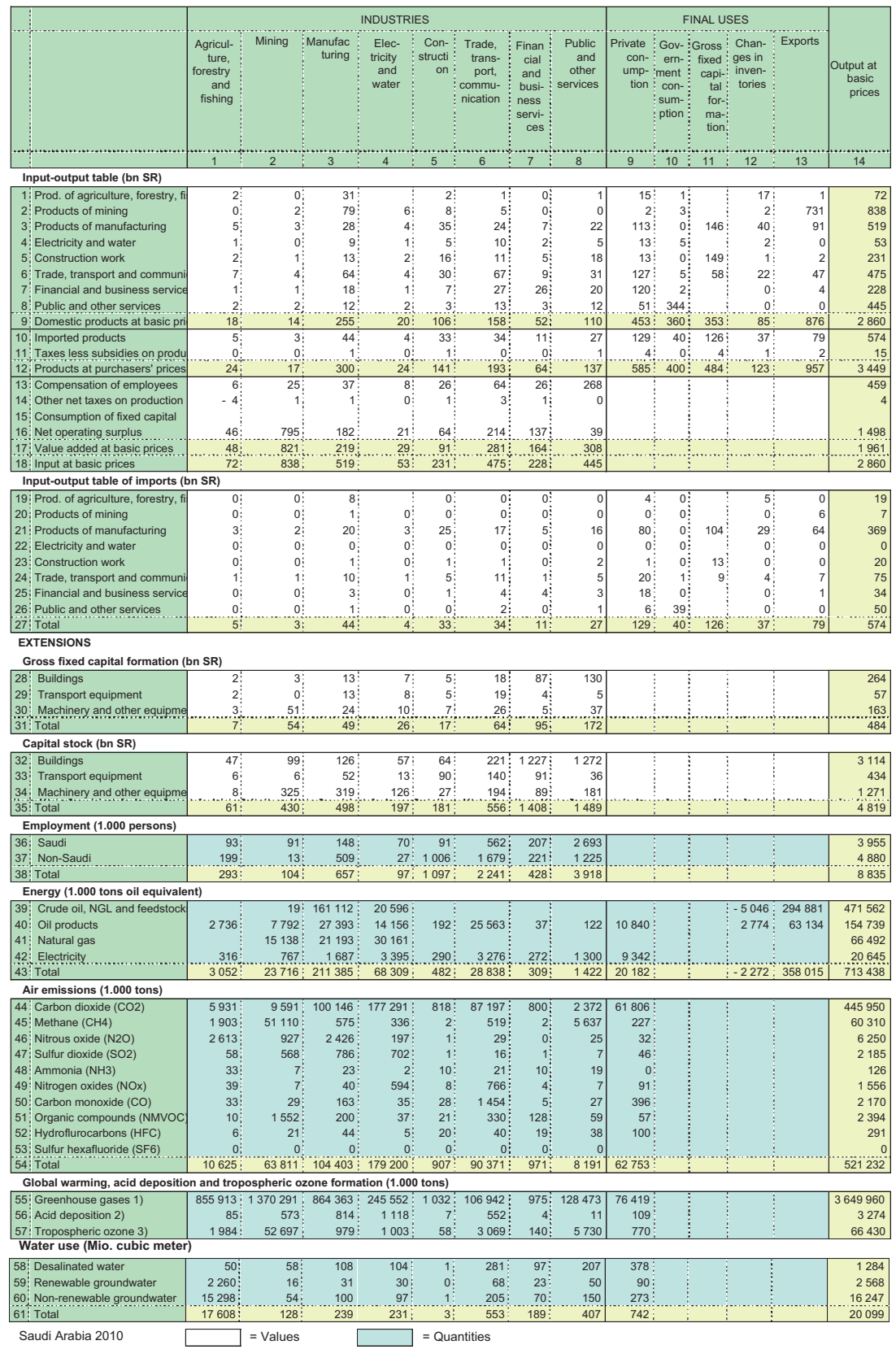


Table 6.7 (continued)

Source: Central Department of Statistics and Information (CDSI), Ministry of Economy and Planning (MOEP), Ministry of Water and Electricity (MOWE), International Energy Agency (IEA), World Bank (WB), World Input-Output Database (WIOD), European Commission (EDGAR), own estimates

Notes: (1) Carbon dioxide $\left(\mathrm{CO}_{2}=1\right)$, methane $\left(\mathrm{CH}_{4}=2 \mathrm{l}\right)$ and nitrous oxide $\left(\mathrm{N}_{2} \mathrm{O}=310\right)$ were transformed with the documented factors to greenhouse gases in $\mathrm{CO}_{2}$-equivalents; (2) sulphur dioxide $\left(\mathrm{SO}_{2}=1\right)$ and nitrogen oxides $\left(\mathrm{NO}_{\mathrm{x}}=0.7\right)$ were transformed with the documented factors to acid depositions in $\mathrm{SO}_{2}$-equivalents; ( 3 ) substances causing tropospheric ozone formation: carbon monoxide ( $\mathrm{CO}$ ), non-methane volatile organic compounds (NMVOC), methane $\left(\mathrm{CH}_{4}\right)$, nitrogen oxides $\left(\mathrm{NO}_{\mathrm{x}}\right)$

environmental policies. If, for example, input-output tables are extended to include environmental information, a solid foundation for environmental policy analysis is provided. Life cycle analysis of products and their impact on the environment and sustainable use of natural resources are two prominent applications. The United Nations recently published the Handbook on Supply, Use and Input-Output Tables with Extensions and Applications (United Nations 2018, p. 518) in which the compilation of physical supply and use tables and extended input-output tables is promoted (Box 6.2). I was a member of the Editorial Board and heavily engaged in drafting the new Handbook for the national accounts.

\subsection{Traditional Input-Output Indicators for GCC Countries}

Only a few GCC countries compile and publish supply, use and inputoutput tables for their national accounts. At the time of writing, national tables were available only for Saudi Arabia and Kuwait.

A comparison of input-output data of Saudi Arabia and Norway reveals that the shares of intermediate consumption of products and gross value added in total output did not change much in both countries between 2005 and 2011 . However, the shares of intermediates in total output were significantly lower in Saudi Arabia than in Norway (31 vs. 46 per cent of output), as were the shares of imported intermediates ( 5 vs. 10 per cent).

The first part of Table 6.8 is devoted to the analysis of direct input coefficients, while in the second part of the table the cumulative input coefficients are explored. The input coefficients reflect the direct input requirements of products for a specific industry, while the cumulative input coefficients represent the direct and indirect input requirements of 


\section{Box 6.2 UN Handbook of Supply, Use and Input-Output Tables}

The United Nations Statistics Division (UNSD) announced in May 2018 that the final draft of the Handbook on Supply, Use and InputOutput Tables with Extensions and Applications is now available on the website of UNSD at:

https://unstats.un.org/unsd/nationalaccount/docs/ SUT_IOT_HB_wc.pdf

From the preface of the UN Handbook:

The Handbook on Supply, Use and Input-Output Tables with Extensions and Applications has been prepared as part of a series of handbooks on national accounting in support of the implementation of the System of National Accounts 2008 (2008 SNA). The objective of this Handbook is to provide a step-by-step guidance for the compilation of Supply and Use Tables (SUTs) and Input-Output Tables (IOTs) and an overview of the possible extensions of SUTs and IOTs which increase their analytical usefulness.

Supply and use tables and the institutional sector accounts constitute the core of the national accounts.

The Institutional Sector Accounts provide detailed information on institutions (Non-financial corporations, Financial corporations, General Government, Households, Non-profit institutions serving households) in the production, the income and the capital account.

Supply and use tables show the relationship between input and output of industries in great detail including the components of value added, intermediate use of products in industries and final demand of products.

Supply and use tables are transformed into symmetric inputoutput tables on the basis of analytical assumption on technology and sales structure. Input-output models are often used to study the impact of exogenous changes of final demand or primary inputs on the rest of the economy. Input-output tables also provide the database for different macroeconomic models.

A social accounting matrix (SAM) comprises all information of the supply and use tables and the institutional sector accounts in one matrix. The SAM is often used as the database of Computable General Equilibrium Model (CGE). 


\section{Box 6.2 (continued)}

The UN Handbook promotes the compilation of physical supply and use tables and extended input-output tables as an integral part of the national accounts. The additional tables offer new opportunities for the analysis of economic diversification and sustainable development models.

products at all stages of production. The cumulative input coefficients are often used to identify the backward linkages of an industry.

In its simplest form, the strength of the backward linkage of an industry is given by the column sum of the direct input coefficients. A more useful and comprehensive measure is provided by the column sum of the Leontief Inverse, which reflects the direct and indirect effects on other industries.

Backward linkages are input-oriented. The industry 'Construction' requires inputs from many other industries and therefore will have strong backward linkages. Forward linkages are output-oriented. The industry 'Electricity' supplies electricity to all other industries, and therefore, this industry is expected to have strong forward linkages (many clients) but weak backward linkages (few inputs).

The column totals of the direct input coefficients and the Leontief Inverse input coefficients reflect the intensity of backward linkages. The row totals of the direct output coefficients and the Ghosh inverse output coefficients show the intensity of forward linkages.

In Table 6.8, the cumulative input coefficients per industry are reported for domestic products (column 2) and total (domestic and imported) products (column 4). The sum of cumulative input coefficients was divided by the number of industries, as the input-output tables comprise a different number of industries in successive years. While the input coefficients for domestic products allow a high degree of substitution between domestic and imported products, the input coefficients for total products reflect technical requirements.

On average, Saudi Arabia reached 95 per cent of the Leontief Inverse for domestic products of Norway. In other words, it can be said that by 2011, Saudi Arabia has reached an international level of industrial 


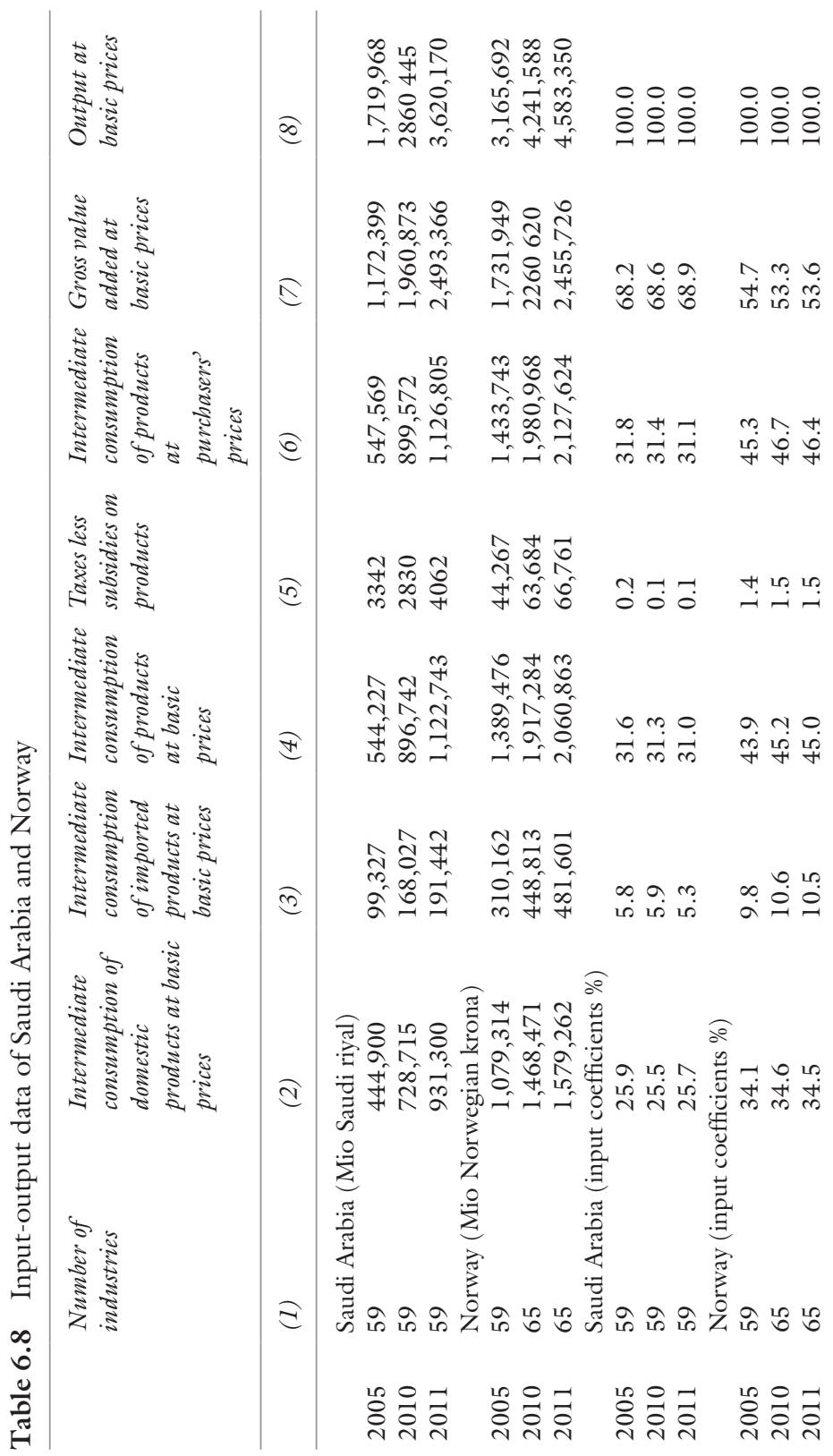


6 ECONOMIC DIVERSIFICATION AND SUSTAINABLE DEVELOPMENT...

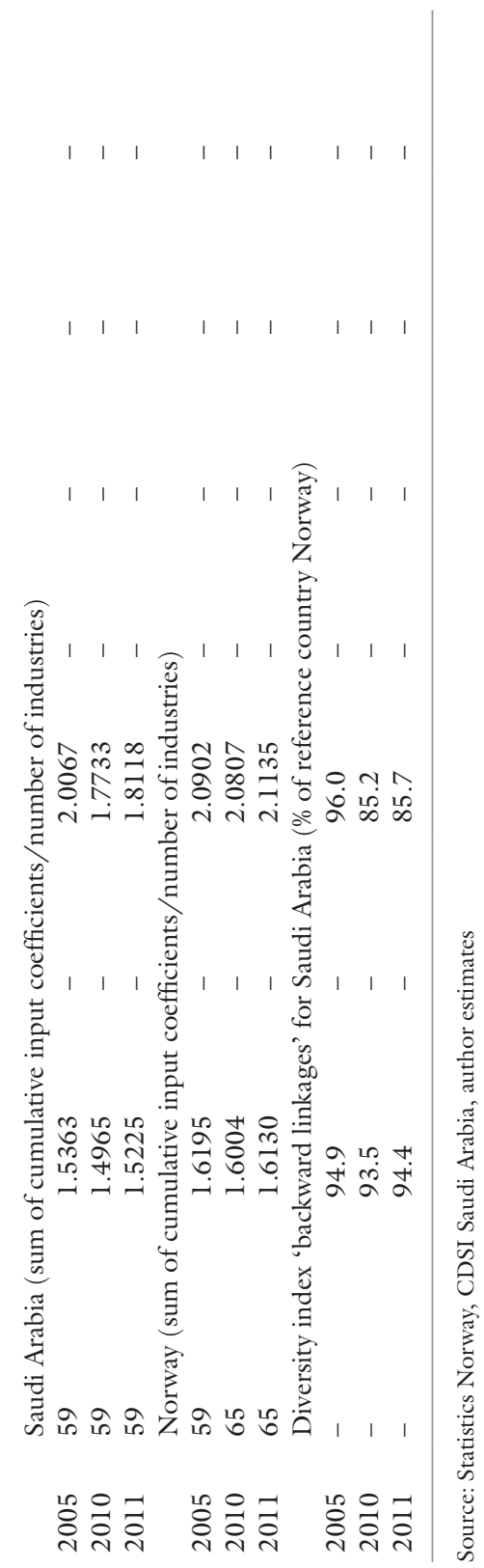


diversification. If imported intermediate inputs are included, the level of diversification appears to have reached 86 per cent of that of Norway.

In Table 6.9, a similar comparison was made for the input-output data of Kuwait and Norway. Kuwait has a long history of compiling input-output data. We used the national input-output tables of Kuwait for 2005, 2010 and 2013. We refrained from using input-output tables which were compiled for the Global Trade Analysis Project (Green 2011 ) as these tables have been generated in a mechanical process with only a few sources. The results for 2005-2013 show a clear trend for the use of domestic intermediates in Kuwait. In 2013, Kuwait, with 32.8 per cent of output, has almost reached the level of Norway (35.2 per cent). However, the share of imported intermediate inputs (5.5 per cent) is much lower than the share in Norway (11.1 per cent). The share of gross value added in output of Kuwait ( 64.8 per cent) is about 10 per cent higher than in Norway ( 54.6 per cent), indicating the potential for more diversification.

The backward linkages for domestic inputs in Kuwait reached 95.8 per cent that of Norway. They even exceeded the level of Norway (108.8 per cent) if imported inputs are included. Thus, in Kuwait, the potential to induce more diversification should not be based on a general policy of promoting more import substitution but rather on a specific policy of encouraging more imports of intermediates.

\subsection{Primary Diversity Measure}

Economic diversity has often been promoted as a means to achieve the economic goals of stability and growth. Empirical studies have been able to relate higher levels of diversity to both economic stability and overall levels of economic activity. Diversity measures, as used in these studies, have tended to be narrowly defined, usually emphasising the distribution of employment across industries. Such measures are unsatisfactory, because they do not capture inter-industrial linkages.

An alternative approach to measuring diversity, based on the technical coefficients matrix of an input-output model, was developed by Wagner and Deller (1998) who show that higher levels of diversification within the theoretical construct of input-output are associated with higher levels of stability. Ahmed Al-Kawaz (2008) has successfully implemented this 


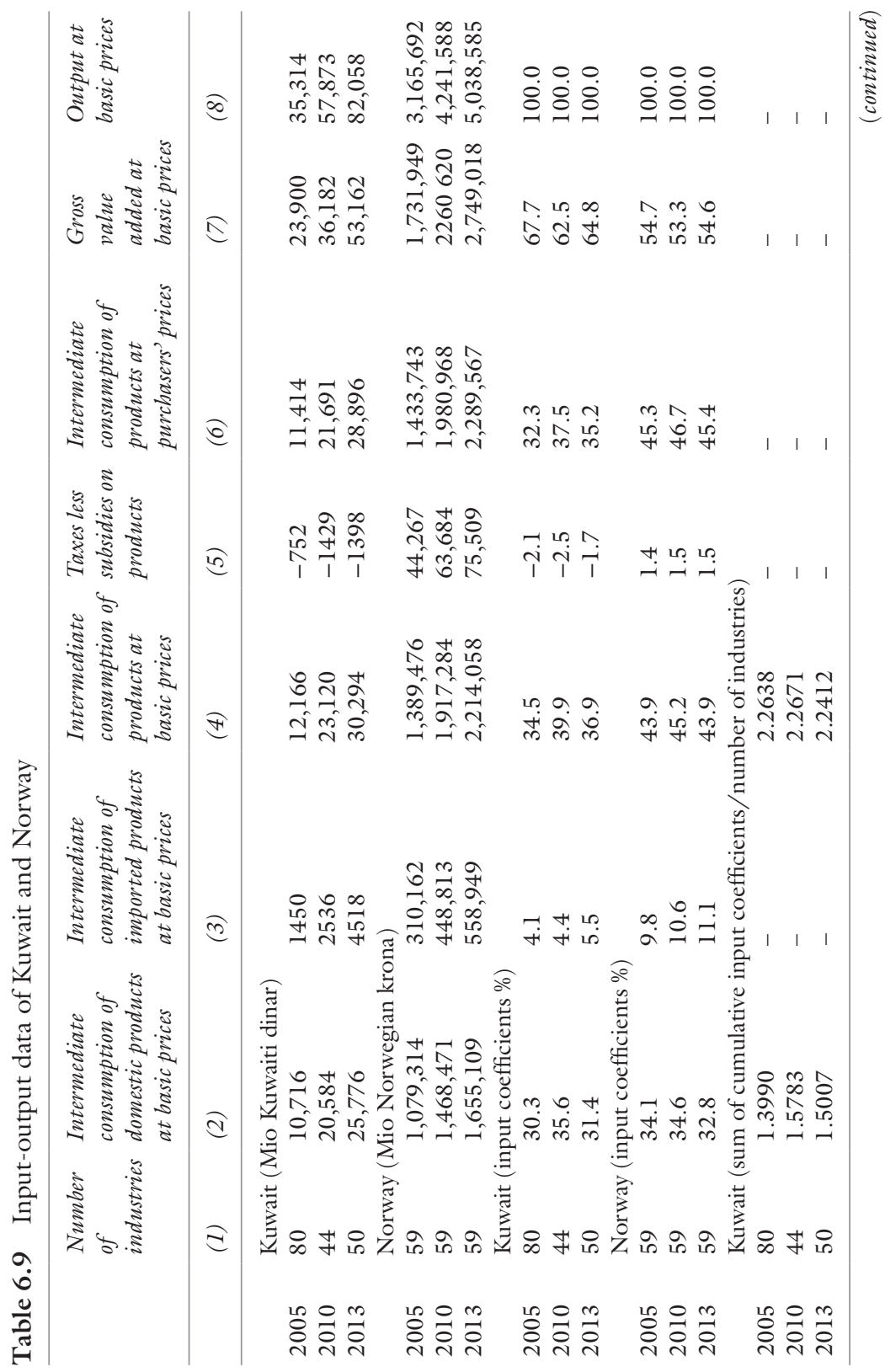




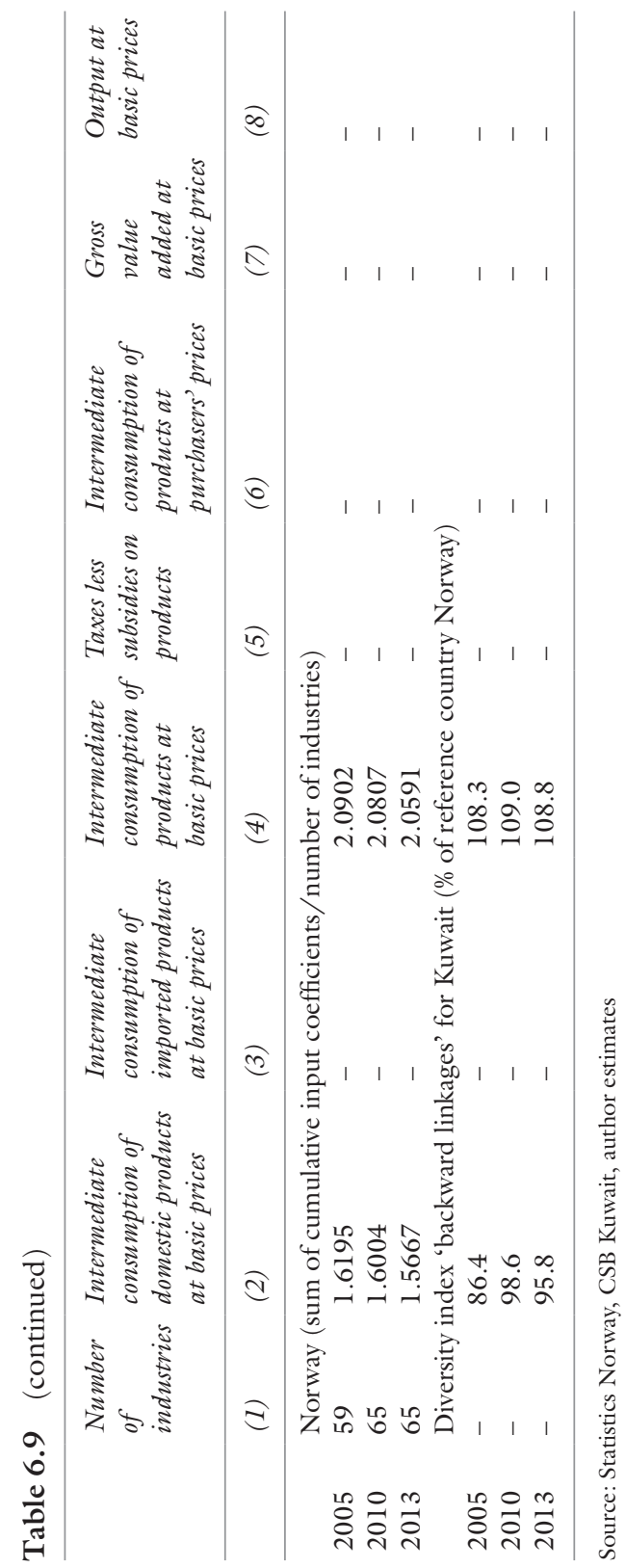


approach for Kuwait using input-output data for Kuwait and Norway for 2000 .

The primary diversity measure of Wagner and Deller puts special emphasis on inter-industry relations and provides the best way to evaluate the diversification of economies. The index is a multiplicative combination of three components:

- The relative size of an economy (SI) - number of indigenous industries

- The density of the economy (DEN)-number of non-zero elements in the Leontief Matrix, indicating the diversity of transactions

- The condition number of the Leontief Matrix $(\mathrm{CN})$-indicator of inter-industry linkages

The Primary Diversity Measure (PDM) is defined as the simple multiplicative combination of these three characteristics, $\mathrm{PDM}=\mathrm{SI}$ * $\mathrm{DEN}$ * $\mathrm{CN}$.

The relative size of the economy is defined as $\mathrm{SI}=\mathrm{N} / \mathrm{N}_{\mathrm{r}}$, where $\mathrm{N}$ is the number of indigenous industries identified in the nation, and $\mathrm{N}_{\mathrm{r}}$ is the number of indigenous industries in the reference country. This measure implies the larger the economy as compared to the base economy, the better. The larger the regional economy, in terms of the number of industries contained within the economy, the greater the ability of the economy to absorb shocks. This is a measure of relative size, but does not contain any information on inter-industry linkages.

The density of the (I - A) matrix is defined as DEN = non-zero/ $N$ * $N$ where non-zero is the number of transactions (non-zero elements) in the Leontief Matrix, and $\mathrm{N}$ is again the number of indigenous industries. The greater the number of non-zero elements contained in the table, the greater the degree of possible inter-industry linkages. This measure does not capture the relative magnitudes of the elements, nor does it capture the positions of these elements within the Leontief Matrix.

The third component measures the degree of inter-industry linkages. The condition number of the Leontief Matrix defines a scalar reflecting the inter-industry linkages.

The condition number is a measure of linear independence. Most commonly, it is used to test for the uniqueness of a solution to a set of linear equations. By definition, an identity matrix, of any size, has a condition 
number equal to one. Any divergence from an identity matrix will cause the condition number to increase. In terms of regional economics, divergence from the identity matrix in terms of the (I - A) matrix implies more purchases from indigenous industries or a greater degree of inter-industry linkages. Thus, the higher the condition number, the more diverse the economy.

Common diversification measures focus on value added of industries and exports and imports of products. The main shortcoming of the traditional measures is the non-consideration of inter-industry nature of economic activities. Input-output indicators for diversification comprise detailed information on supply and demand. They cover intermediate consumption of domestic and imported products, value added by industry and final uses of products (consumption, investment, exports). The Primary Diversity Index puts special emphasis on inter-industry relations. In our opinion, this indicator is the best choice to evaluate the diversification of economies (Box 6.3).

\section{Box 6.3 Input-Output-Based Primary Diversity Index}

An alternative approach to measuring diversity based on the technical coefficients matrix of an input-output model was developed by Wagner and Deller and applied to the 50 US states. Empirical results suggest that higher levels of diversification are associated with higher levels of stability.

Ahmed Al-Kawaz implemented this approach also for Kuwait.

The diversity measure of Wagner and Deller is a multiplicative combination of three components:

Relative size of an economy (SI) - Number of indigenous industries

Density of the economy (DEN)-Number of non-zero elements in the Leontief Matrix indicating the diversity of transactions

The condition number of the Leontief Matrix $(\mathrm{CN})$-Scalar measure of the inter-industry linkages with the economy as captured in the Leontief matrix

The Primary Diversity Measure $\left(\mathrm{PDM}_{\mathrm{i}}\right)$ for a country $(\mathrm{i})$ is defined as the simple multiplicative combination of these three characteristics $\mathrm{PDM}_{\mathrm{i}}=\mathrm{SI}_{\mathrm{i}}$ * $\mathrm{DEN}_{\mathrm{i}}$ * $\mathrm{CN}_{\mathrm{i}}$.

The relative size of the economy is defined as $S_{i}=N_{i} / N_{r}$, where $\mathrm{N}$ is the number of indigenous industries in country (i) and $\mathrm{N}_{\mathrm{r}}$ is the number of indigenous industries in the reference country. 


\section{Box 6.3 (continued)}

The density of the economy is defined as $\mathrm{DEN}_{\mathrm{i}}=$ non-zero $\mathrm{i} / \mathrm{N}_{\mathrm{i}}$ * $\mathrm{N}_{\mathrm{i}}$, where non-zero is the number of transactions in the Leontief Matrix (I-A), and $\mathrm{N}_{\mathrm{i}}$ is again the number of indigenous industries in country (i).

The third component measures the degree of inter-industry linkages. The condition number of the Leontief matrix defines a scalar reflecting the inter-industry linkages. The condition number is defined as

$\mathrm{CN}_{\mathrm{i}}=\|(\mathrm{I}-\mathrm{A})\|\left\|(\mathrm{I}-\mathrm{A})^{-1}\right\|=\delta_{1}(\mathrm{I}-\mathrm{A}) / \delta_{\mathrm{s}}(\mathrm{I}-\mathrm{A})$ where

$\|(\mathrm{I}-\mathrm{A})\|$ is the 2 -norm of the $(\mathrm{I}-\mathrm{A})$ matrix,

$\left\|(\mathrm{I}-\mathrm{A})^{-1}\right\|$ is the 2 -norm of the $(\mathrm{I}-\mathrm{A})^{-1}$ (the Leontief inverse matrix),

$\delta_{l}(I-A)$ is the largest singular value of the (I-A) matrix, and

$\delta_{s}(I-A)$ is the smallest singular value of the (I - A) matrix, respectively.

The Primary Diversity Index is defined as PDI $=\mathrm{PDM}_{\mathrm{i}} / \mathrm{PDM}_{\mathrm{r}}$.

$\mathrm{i}=$ Country $\mathrm{i}$

$r=$ Reference country $r$

Sources:

John E. Wagner and Steven C. Deller (1998): Measuring the Effects of Economic Diversity on Growth and Stability, in: Land Economics, Vol. 74, No. 4. pp. 541-556; Ahmed Al-Kawaz (2008): Economic Diversification: The Case of Kuwait with Reference to Oil Producing Countries, in Journal of Economic Cooperation, 29, 3, pp. 23-48.

The results of the input-output-based diversity index for Saudi Arabia compared to Norway are presented in Table 6.10.

We used the input-output tables of the OECD (2018) for this analysis. All input-output tables of the database show 34 industries. In Norway and Saudi Arabia, only 33 indigenous industries were reported. This is why the size (SI) in Table 6.13 is always reported with 1.0 for all years. The number of non-zero elements in the table of Saudi Arabia was somewhat smaller than in Norway. This is why the density (DEN) of Saudi Arabia is a bit lower. The condition number $(\mathrm{CN})$ reflects inter-industry linkages: in all years, it is lower in Saudi Arabia than in Norway, but the difference is not strikingly high. Consequently, the Primary Diversity Index of Saudi Arabia was lower than that of Norway for all years, but the distance has 
Table 6.10 Input-output diversity index

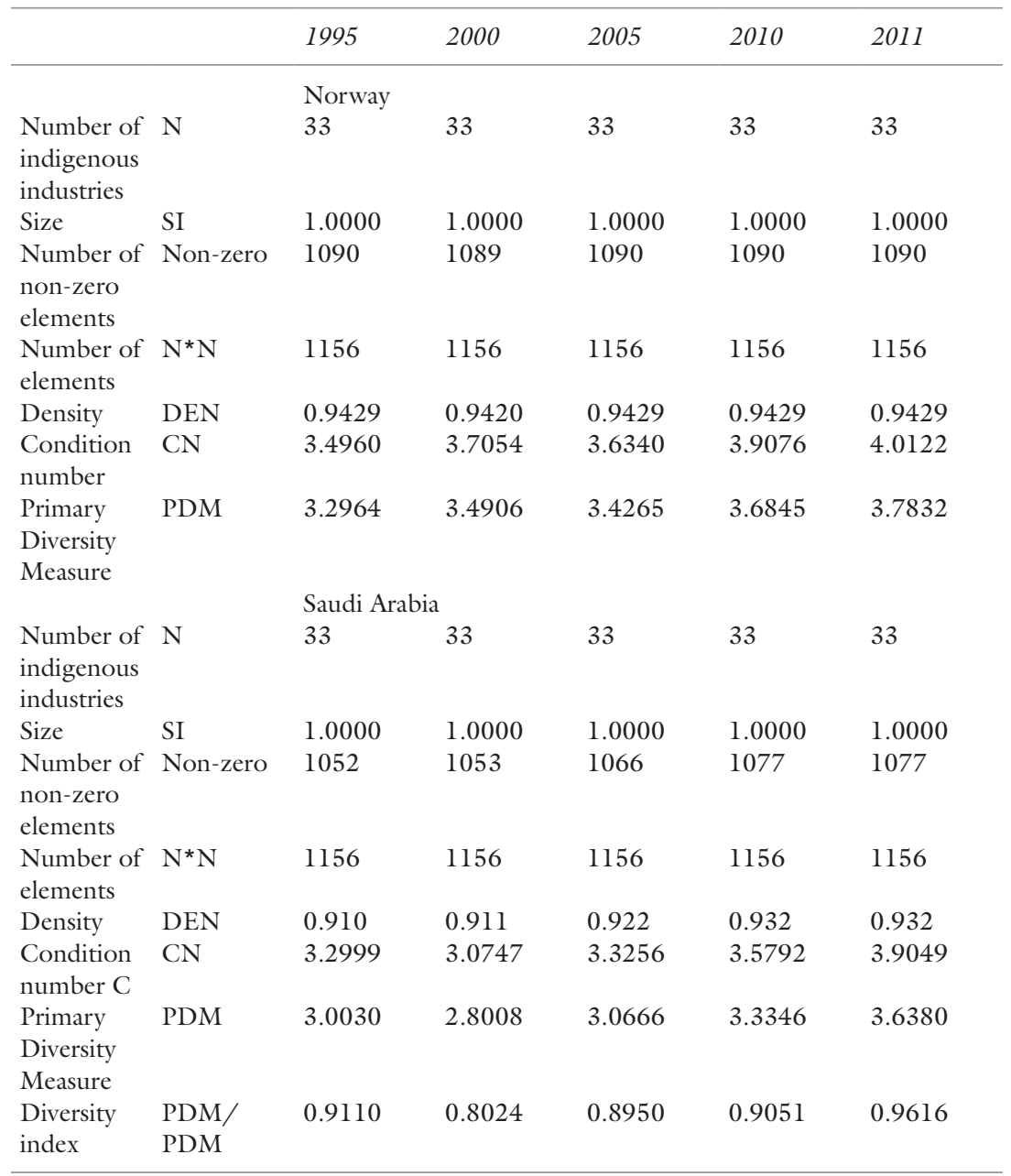

Source: OECD Input-Output Tables

shrunk. In 1995, Saudi Arabia was at 91.1 per cent of the corresponding level of Norway, but by 2011 , it had increased to 96.2 per cent. Therefore, by 2011 , Saudi Arabia almost reached the diversity level of Norway. This is a considerable achievement of the Saudi development policy. 


\section{Sustainable Development of Nations: Adjusted Net National Income and Savings}

Since a long time, the World Bank is engaged in measuring sustainable development of nations (World Bank 2001). Given the exhaustible nature of oil resources, the long-term strategy for economic sustainability of the oil-producing countries must be to transform the non-renewable natural capital into other forms of capital like machinery, buildings and human capital, and so increase the gross national income per capita (Beutel et al. 2013). In the World Bank's World Development Indicators (World Bank 2018), we find two prominent indicators for sustainable economic development:

- Adjusted net national income, which is gross national income (GNI) minus consumption of fixed capital and natural resources depletion.

- Adjusted net savings, which are equal to net national savings plus education expenditure and minus energy depletion, mineral depletion, net forest depletion, and carbon dioxide and particulate emissions damage.

\subsection{Adjusted Net National Income}

Adjusted net national income is calculated by subtracting consumption of fixed capital and the depletion of natural resources from gross national income (GNI). Consumption of fixed capital reflects the decline of manmade capital (buildings, machinery, transport equipment), while the depletion of natural resources measures the decline in non-renewable natural resources through extraction.

Gross domestic product (GDP)

+ Net income from abroad

$=$ Gross national income $(\mathrm{GNI})$

- Consumption of fixed capital

$=$ Net national income (NNI)

- Natural resources depletion

= Adjusted net national income 
Where:

Gross domestic product at purchaser's prices is the sum of gross value added by all resident producers in the economy plus any product taxes and minus any subsidies not included in the value of the products.

Net income from abroad includes the net labour income and net property and entrepreneurial income components of the SNA.

Gross national income (GNI) is the sum of value added by all resident producers plus any product taxes (less subsidies) not included in the valuation of output plus net receipts of primary income (compensation of employees and property income) from abroad.

Consumption of fixed capital represents the replacement value of capital used up in the process of production.

Net national income is gross national income (GNI) less consumption of fixed capital.

Natural resource depletion is the ratio of the value of the stock of natural resources to the remaining reserve lifetime (capped at 25 years). It covers coal, crude oil and natural gas. The World Bank provides valuable information for 10 minerals, 4 energy sources and the net forest depletion.

Adjusted net national income is GNI minus consumption of fixed capital and natural resources depletion.

\subsection{Adjusted Net Saving}

Adjusted net saving is a national accounting aggregate designed to measure the net change in assets in a national balance sheet that includes natural and human capital. The gross stock of natural capital, produced capital and human capital is growing if the adjusted net savings of a nation are positive.

There is an intrinsic link between change in the wealth of a nation and the sustainability of a development path. If genuine (adjusted) savings are negative at any point in time, then welfare in the future will be less than current welfare. Therefore, adjusted net saving can be regarded as a sustainability indicator. 
Specifically, the World Bank's definition of adjusted net savings is as follows:

Gross national savings

Consumption of fixed capital

$=$ Net savings

+ Education expenditure

- Energy depletion

- Mineral depletion

- Net forest depletion

- Carbon dioxide emissions damage

- Particulate emissions damage

= Adjusted net savings (genuine savings)

Where:

Net national savings are equal to gross national savings less the value of consumption of fixed capital.

Education expenditure refers to the current operating expenditures in education, including wages and salaries and excluding capital investments in buildings and equipment.

Energy depletion is the ratio of the value of the stock of energy resources to the remaining reserve lifetime (capped at 25 years). It covers coal, crude oil and natural gas.

Mineral depletion is the ratio of the value of the stock of mineral resources to the remaining reserve lifetime (capped at 25 years). It covers tin, gold, lead, zinc, iron, copper, nickel, silver, bauxite and phosphate.

Net forest depletion is calculated as the product of unit resource rents and the excess of wood harvest over natural growth.

Carbon dioxide damage is estimated to be $\$ 20$ per ton of carbon (the unit damage in 1995 US dollars) times the number of tons of carbon emitted.

Particulate emissions damage is the damage due to exposure of a country's population to ambient concentrations of particulates measuring less than 2.5 microns in diameter (PM2.5), ambient ozone pollution and 
indoor concentrations of PM2.5 in households cooking with solid fuels. Damages are calculated as foregone labour income due to premature death. Estimates of health impacts from the Global Burden of Disease Study 2015 are for 1990, 1995, 2000.

\subsection{Test for Sustainable Development}

An economy is sustainable if it saves more than the depreciation on its man-made and natural capital. In Table 6.11, an assessment has been made for all GCC countries and Norway.

The highest adjusted national income per capita (78.515 \$/person) and adjusted net national saving per capita (22.363 \$/person) were achieved in Norway. Among GCC countries, Qatar had the highest adjusted national income per capita $(67.443 \$$ /person $)$, followed by UAE (38.670 \$/person) and Kuwait $(37,781$ \$/person). Qatar had also the highest adjusted net national saving per capita (34.570 \$/person) followed by Kuwait (13.421 \$/person).

Among the GCC countries, only Oman ( $-1.052 \$$ /person) recorded negative adjusted savings, and its combined capital stock of man-made capital and natural capital declined in 2014. This is well in line with the lowest level of the adjusted net national income per capita $(10,556 \mathrm{\$} /$ person). The net income from abroad was negative throughout the years.

Tables 6.12-6.17 contain complete information on a country by country basis, showing the evolution of sustainable development of the six GCC countries for the 20 years 1995-2015.

Earlier in the text in Table 6.5, it was reported that Bahrain had in 2016 the lowest oil dependency (13.5\% of gross value added) and Kuwait (51.4\% of gross value added) the highest oil dependency among the GCC countries. The test for sustainable development of Bahrain in Table 6.12 reveals that the adjusted net national income and the adjusted net saving are low compared to other GCC countries. In 2014, final consumption expenditure is high $(68.2 \%$ of GNI) and education expenditure is low (2.9\% of GNI), both resulting in a low adjusted savings ratio $(10.3 \%$ of GNI).

The prospects for Kuwait in Table 6.13 are brighter. Despite substantial allocations for the depletion of natural resources, the savings ratios throughout the period 2000-2014 are impressive. The positive performance of the savings ratio is certainly supported by relatively low 


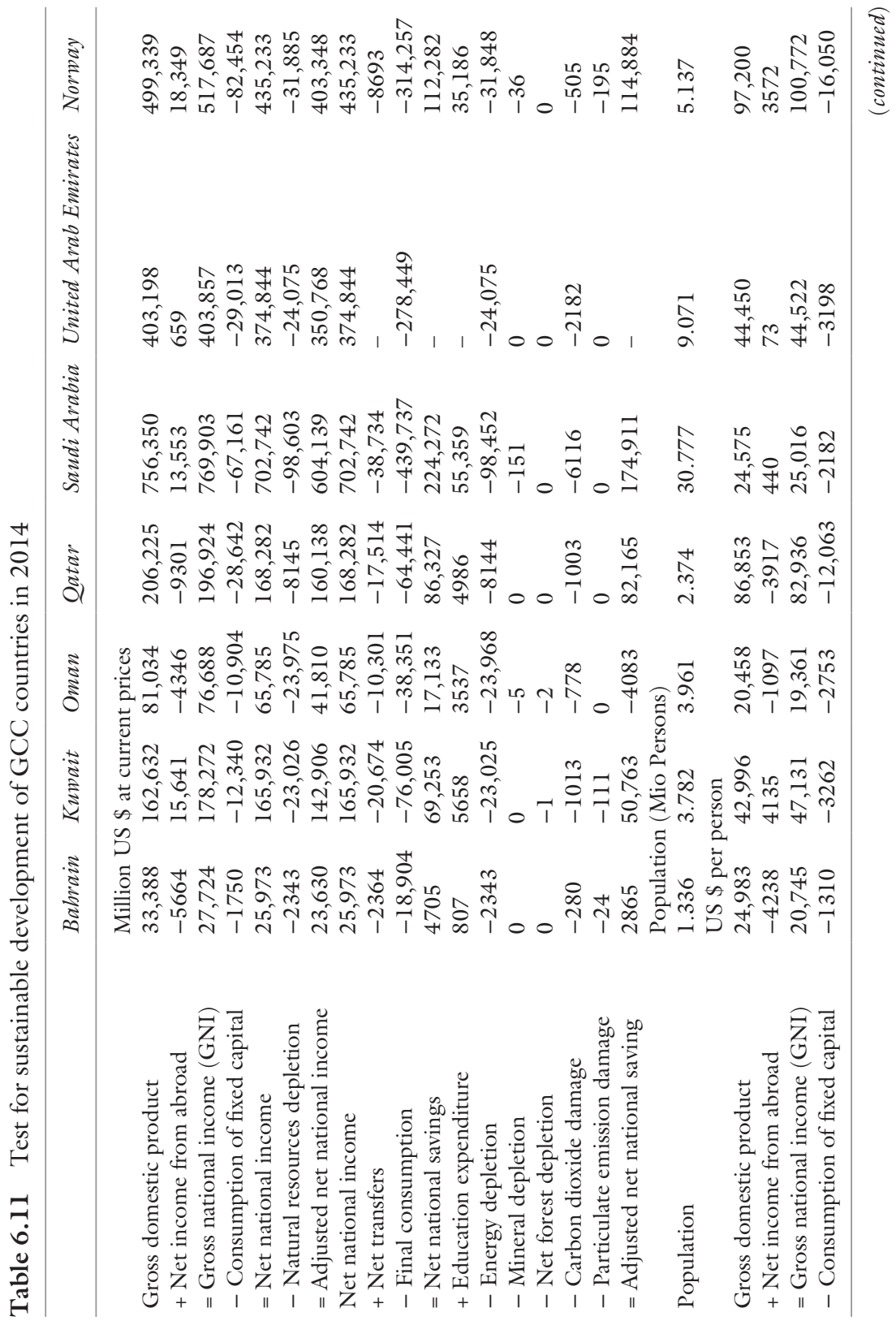




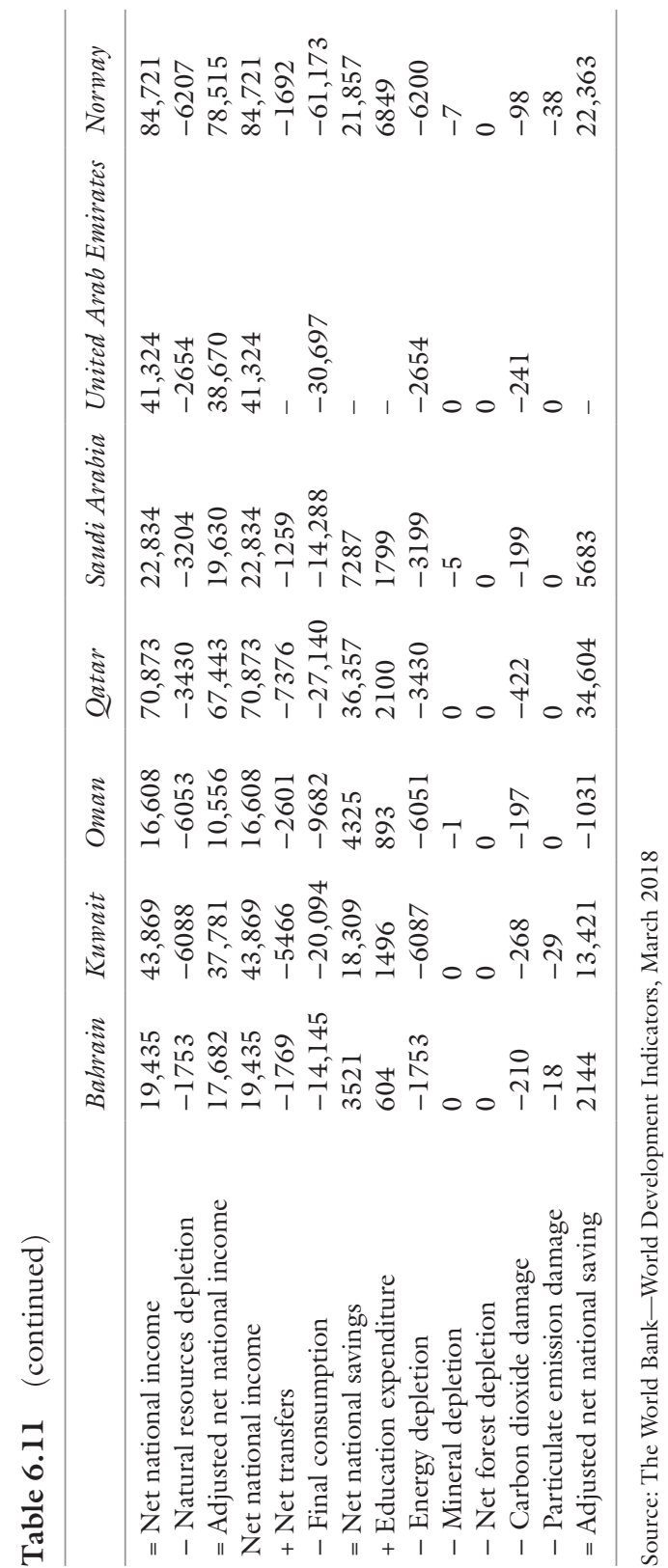




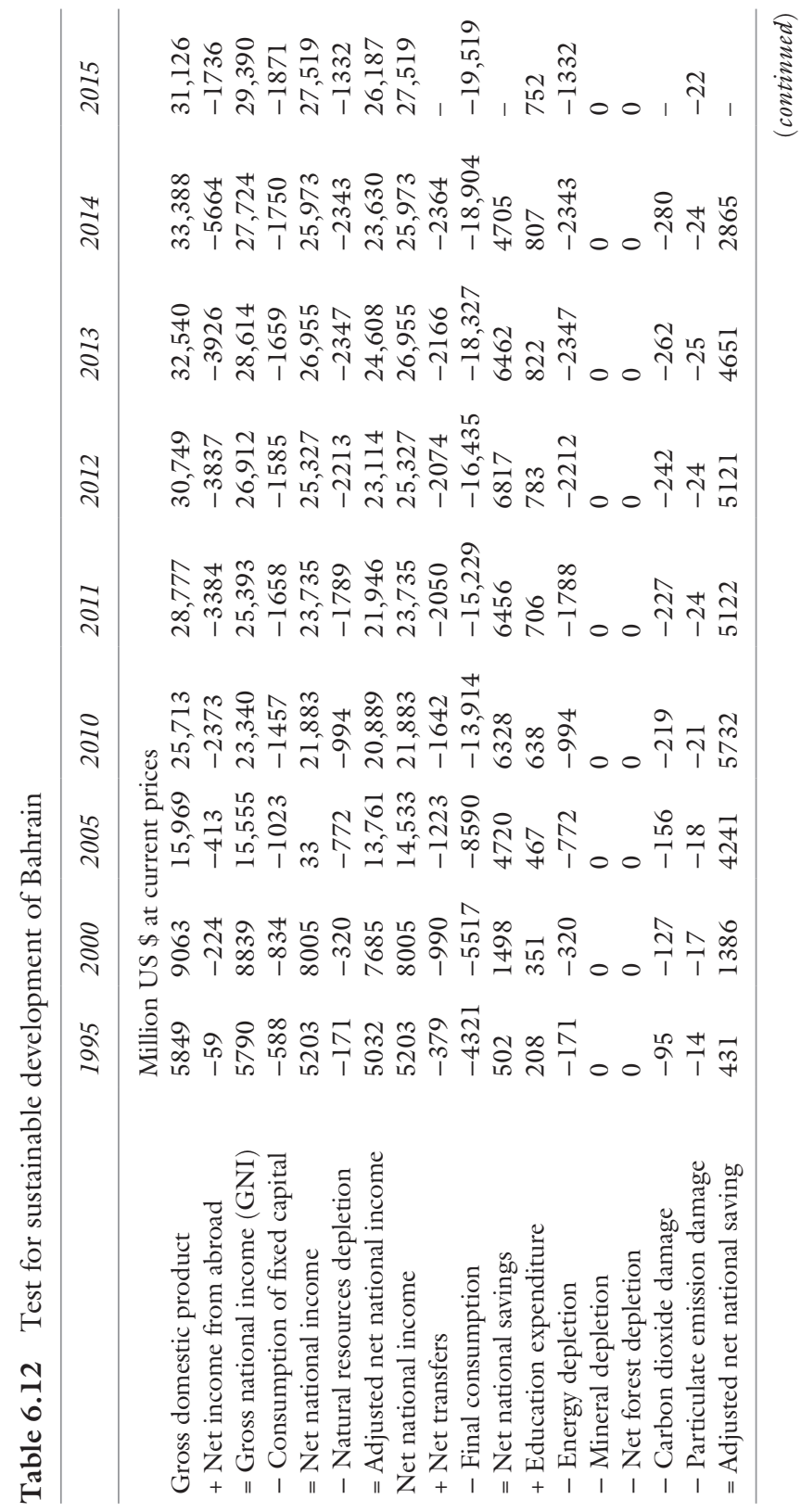




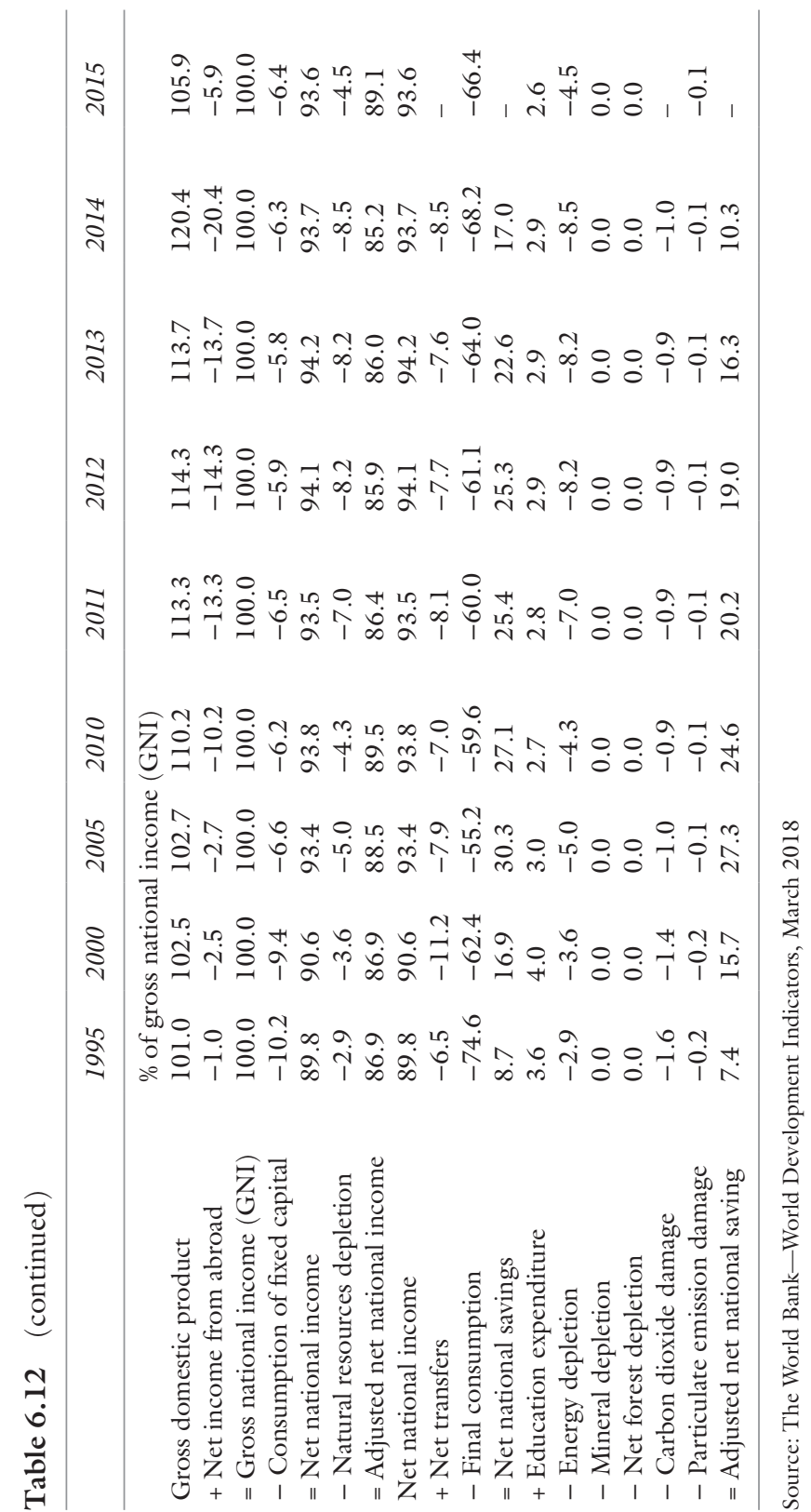




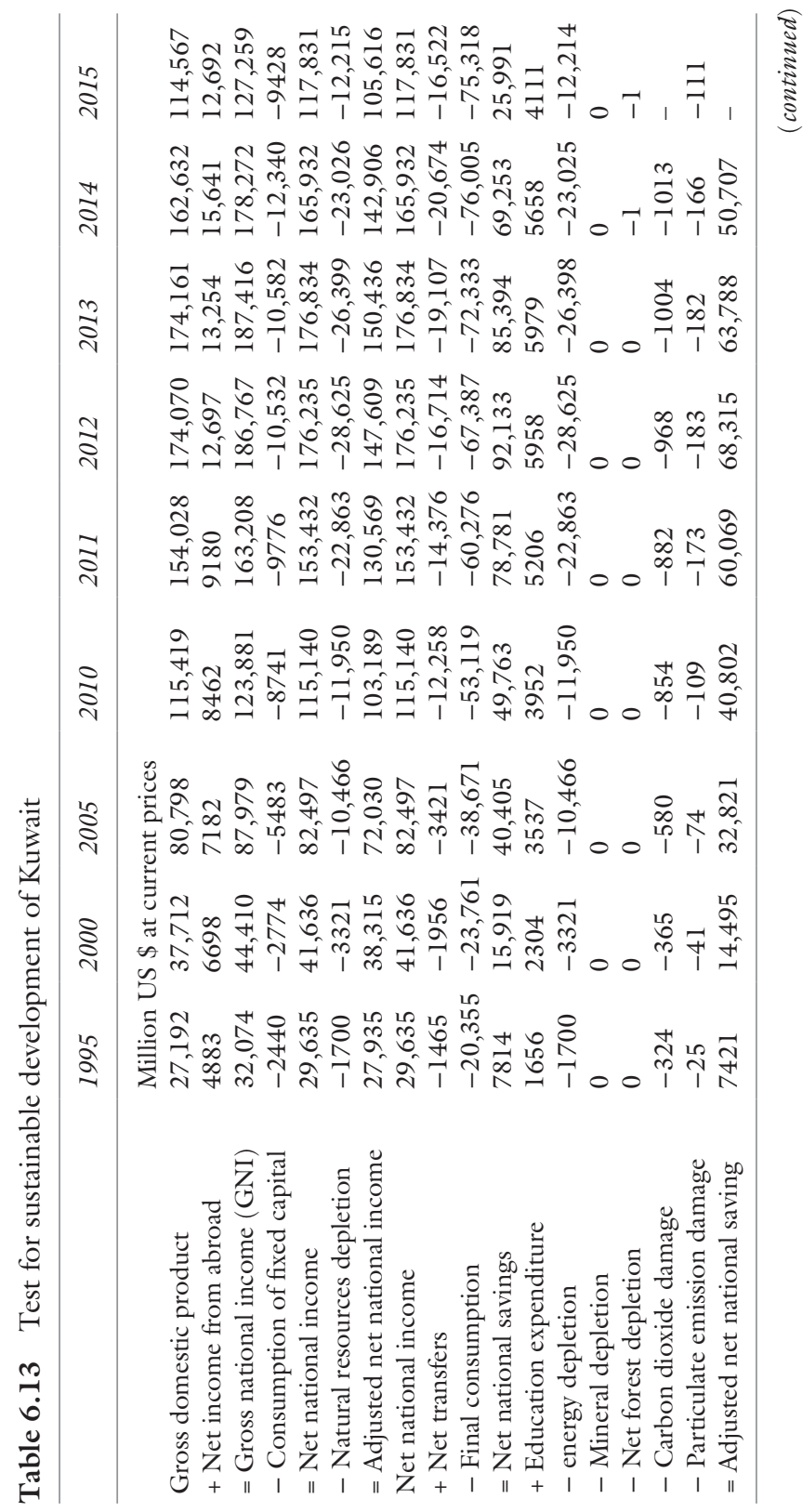




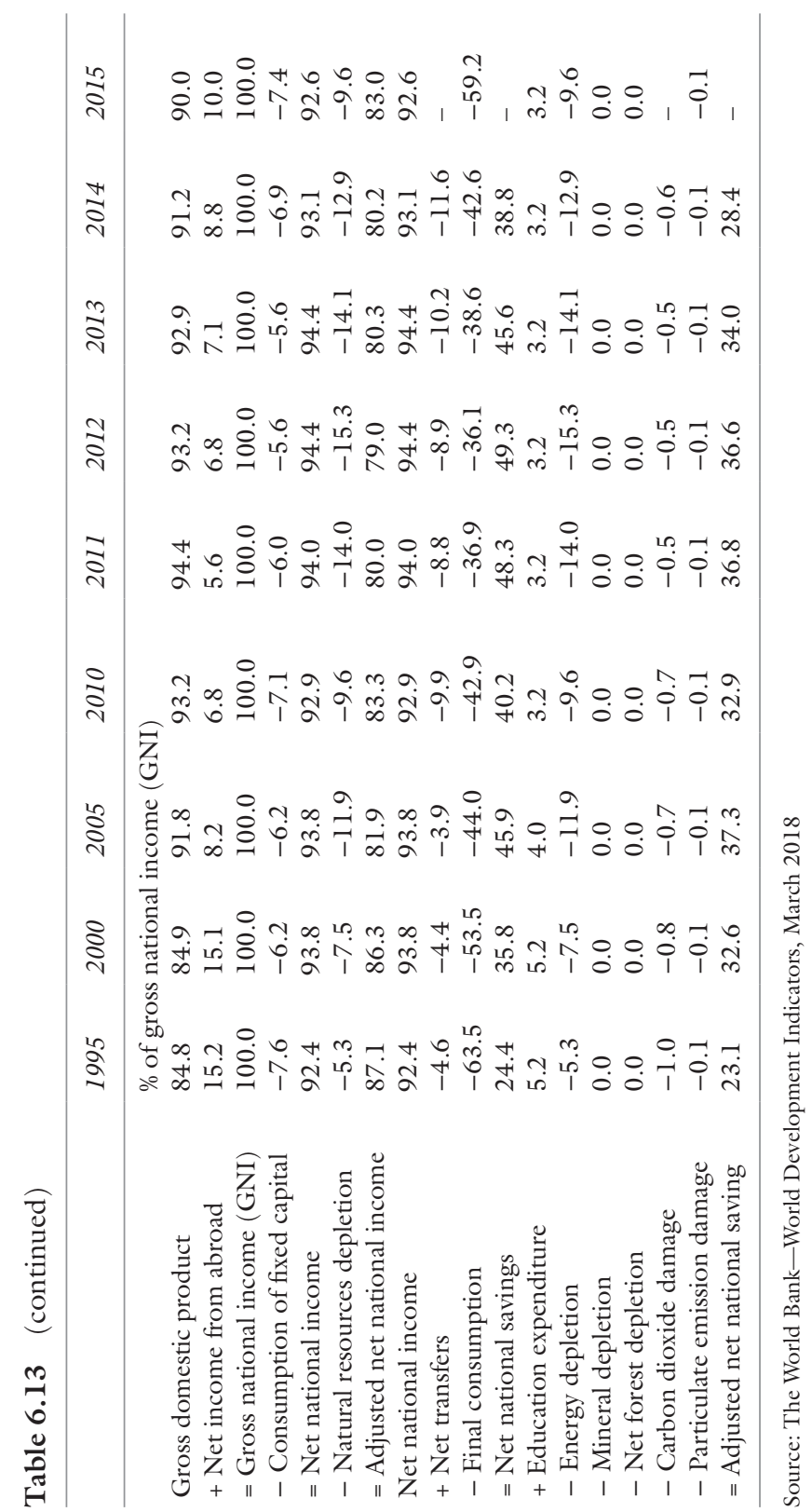




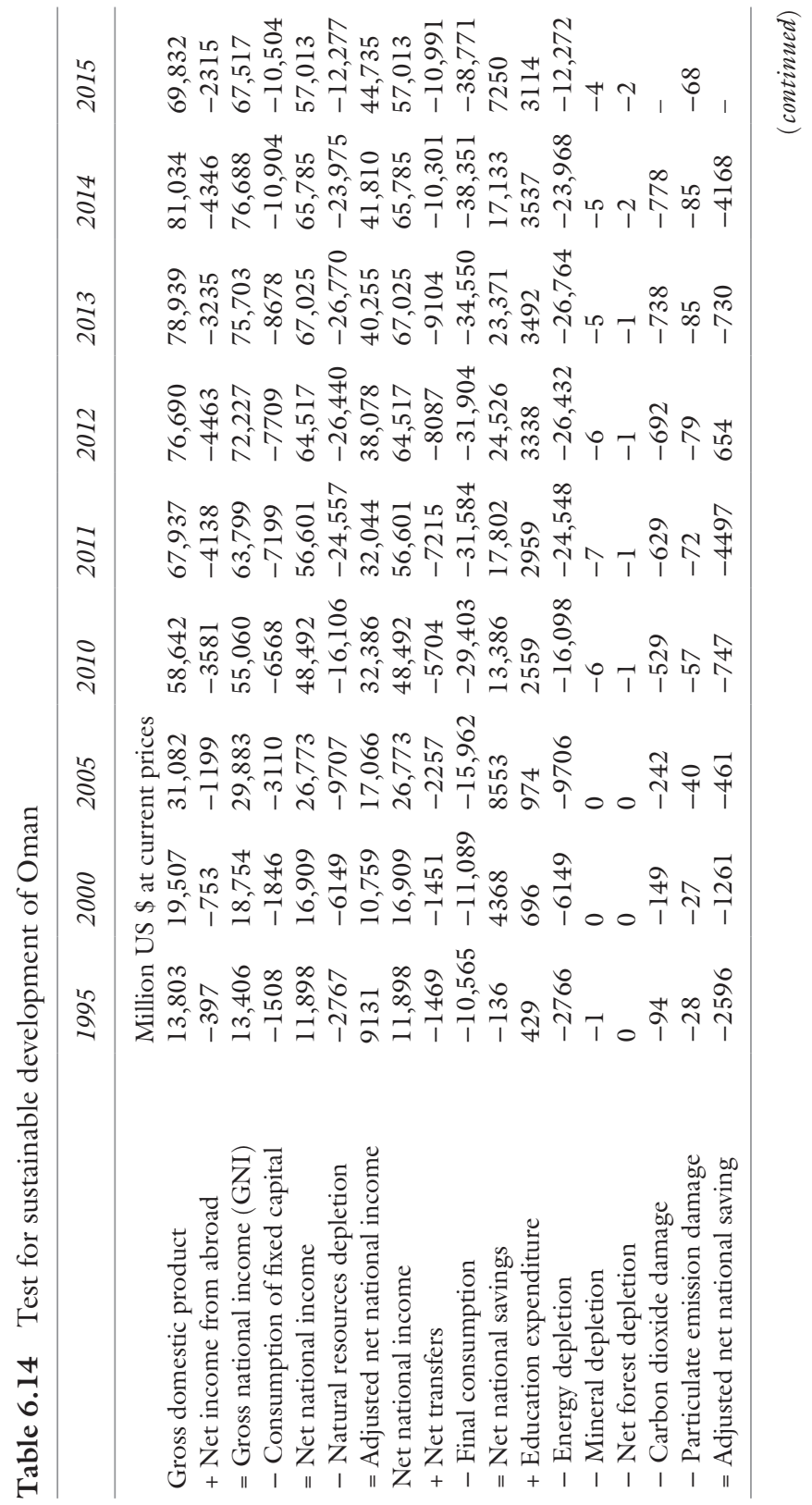




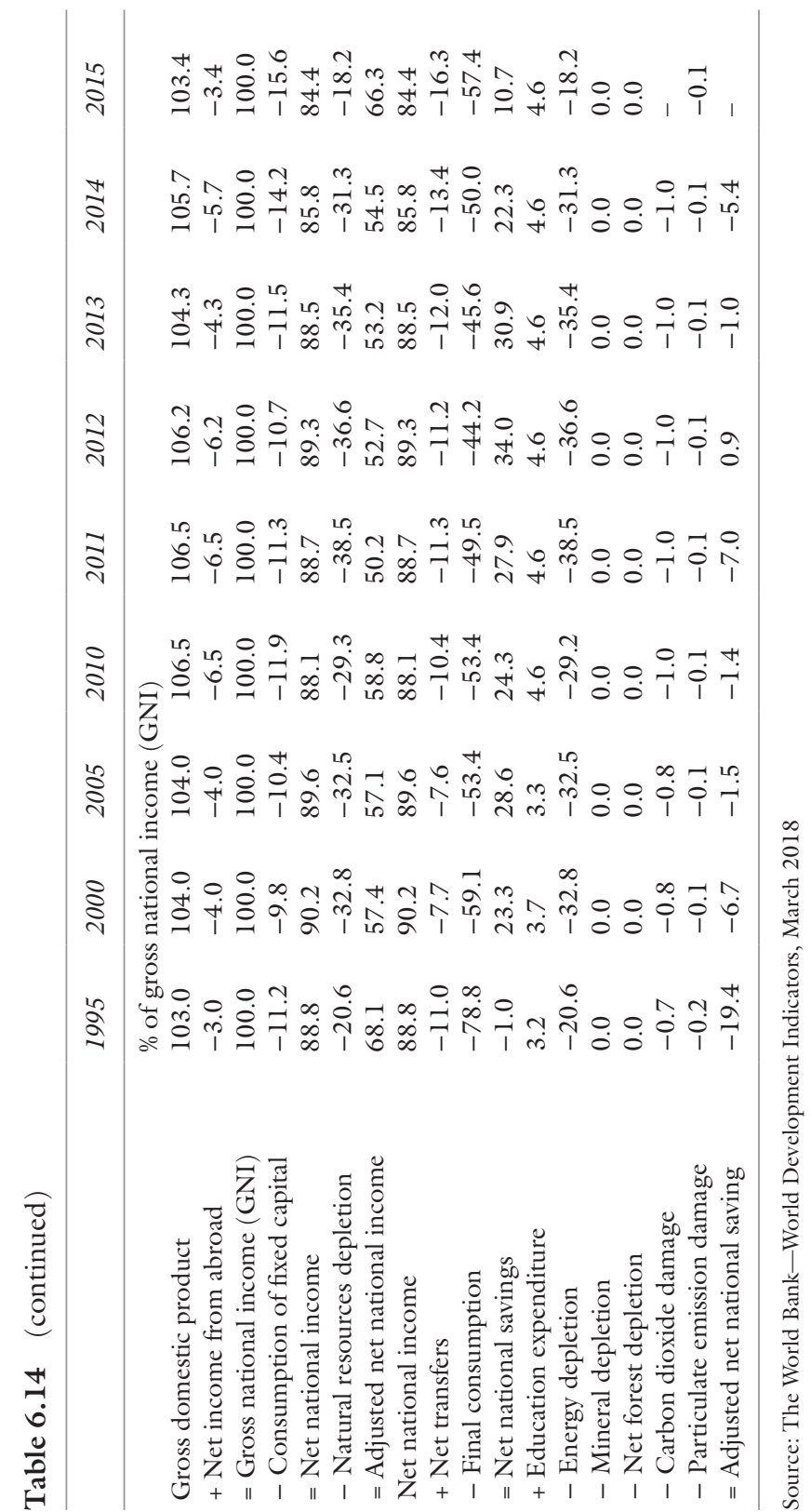




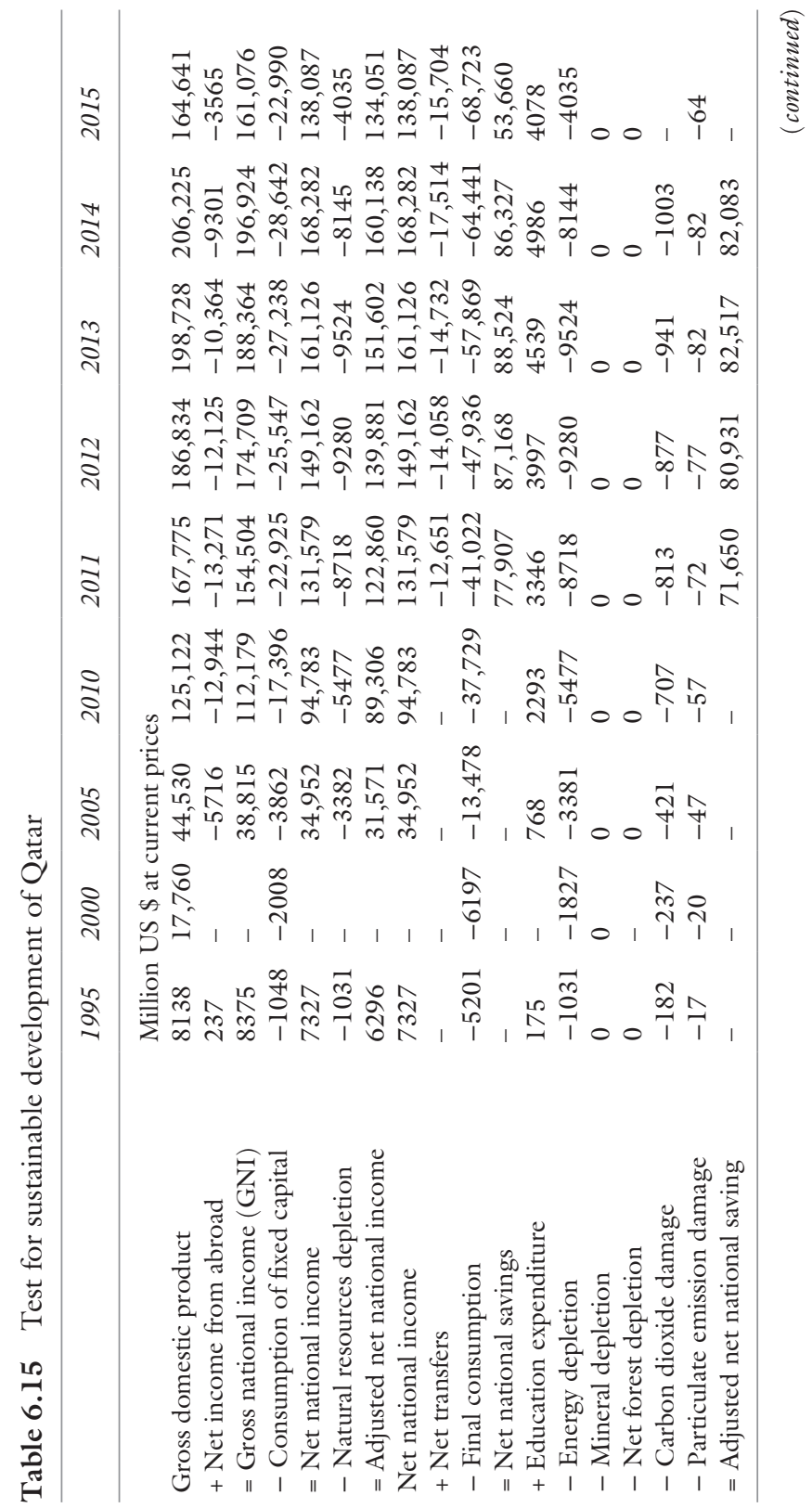




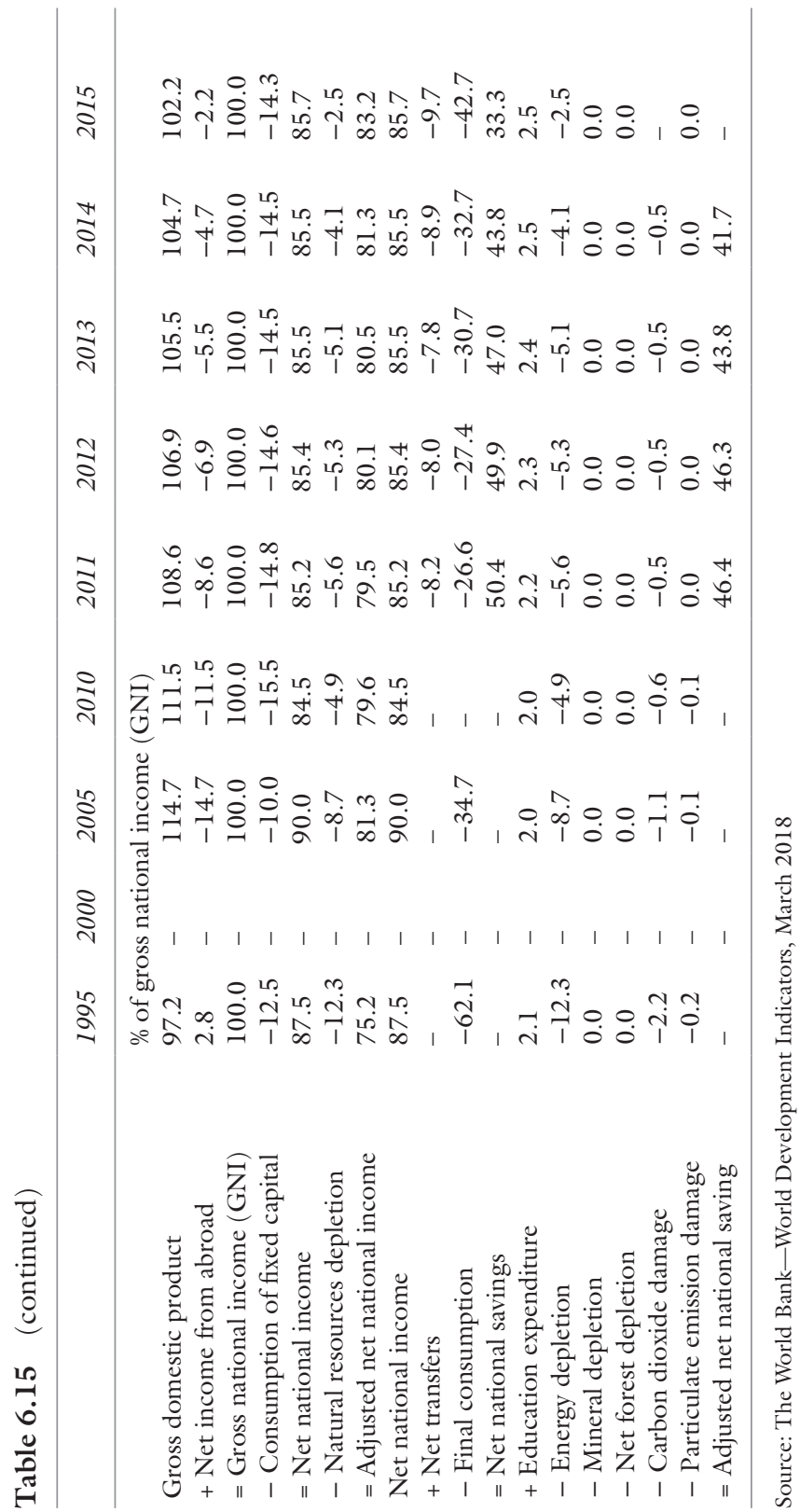




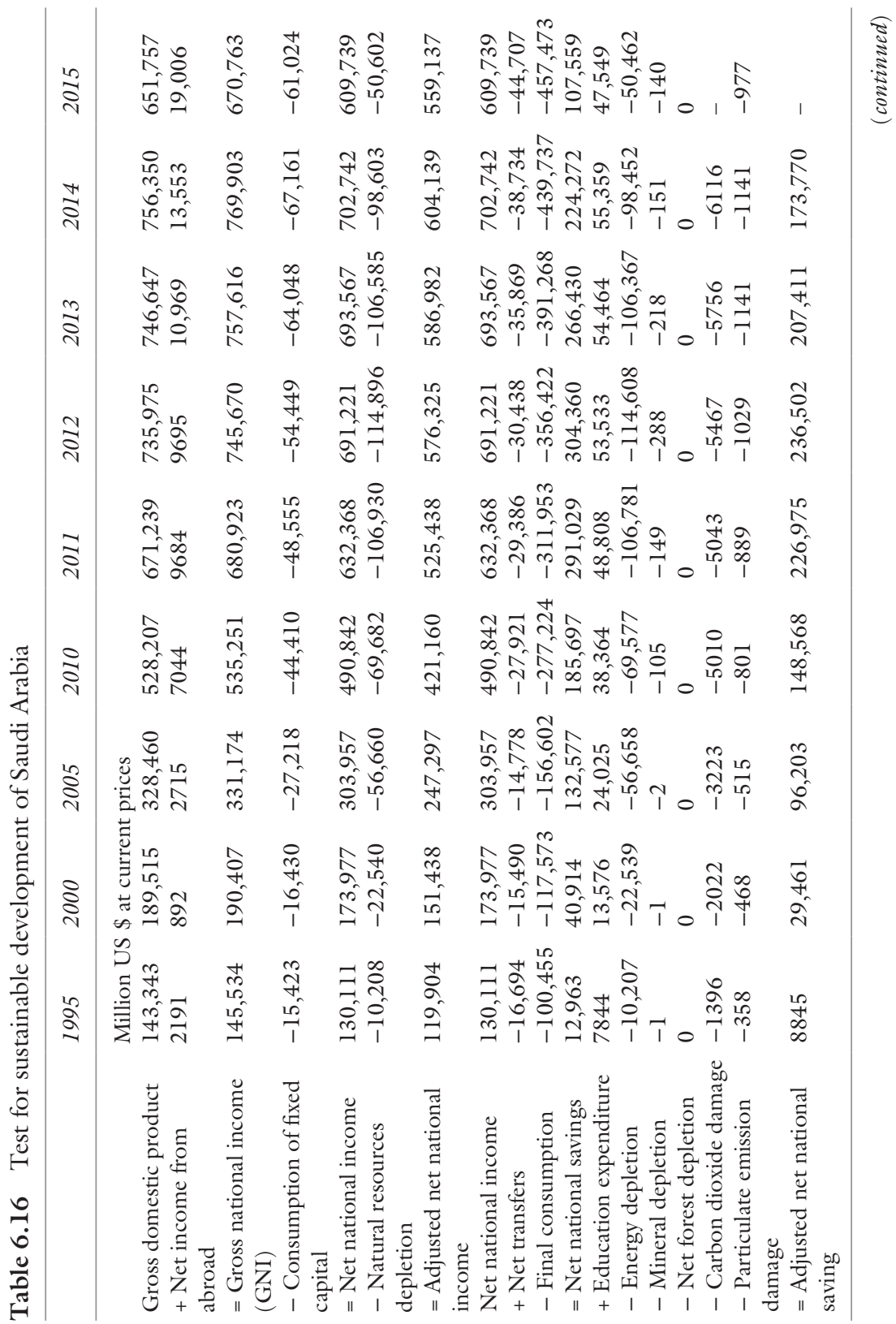




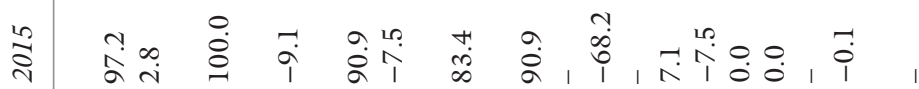

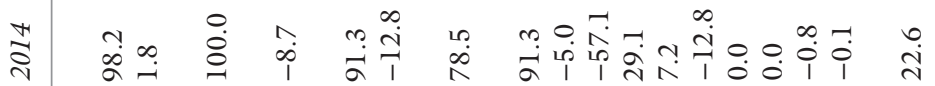

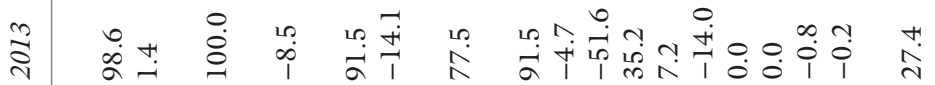

તิ

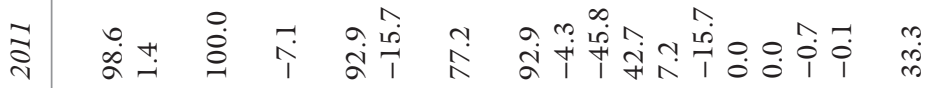

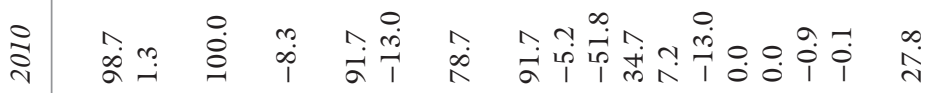

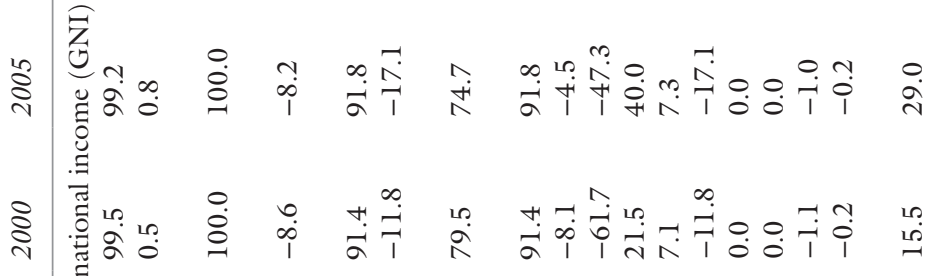
峁

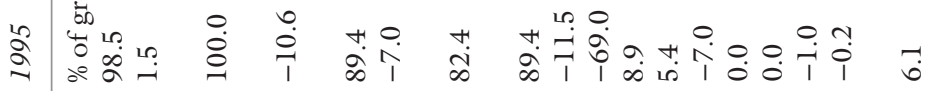




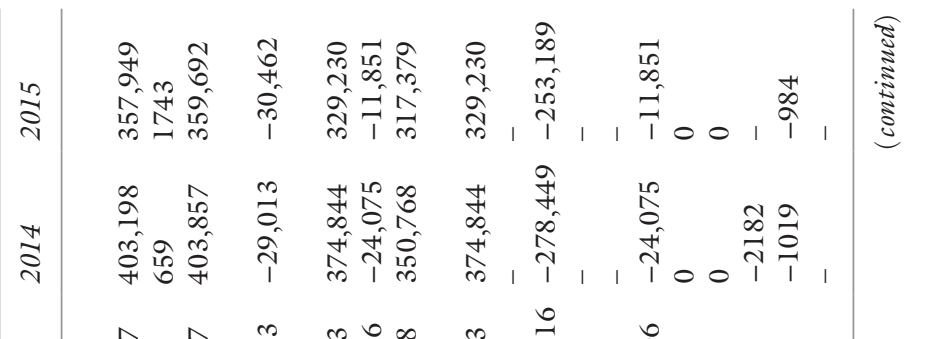

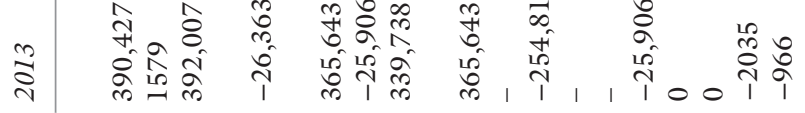

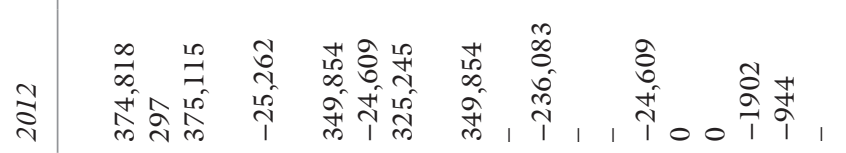

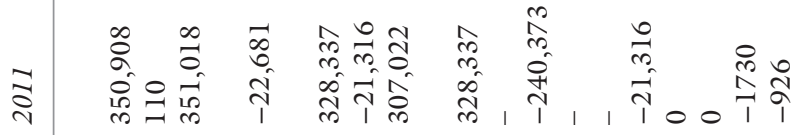

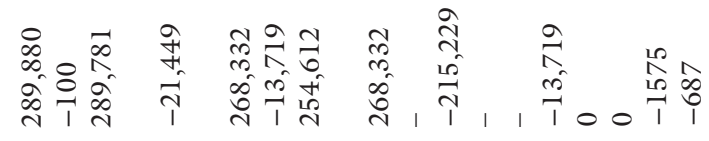

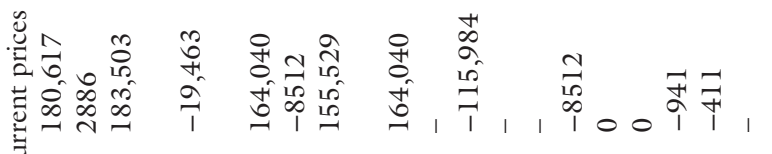




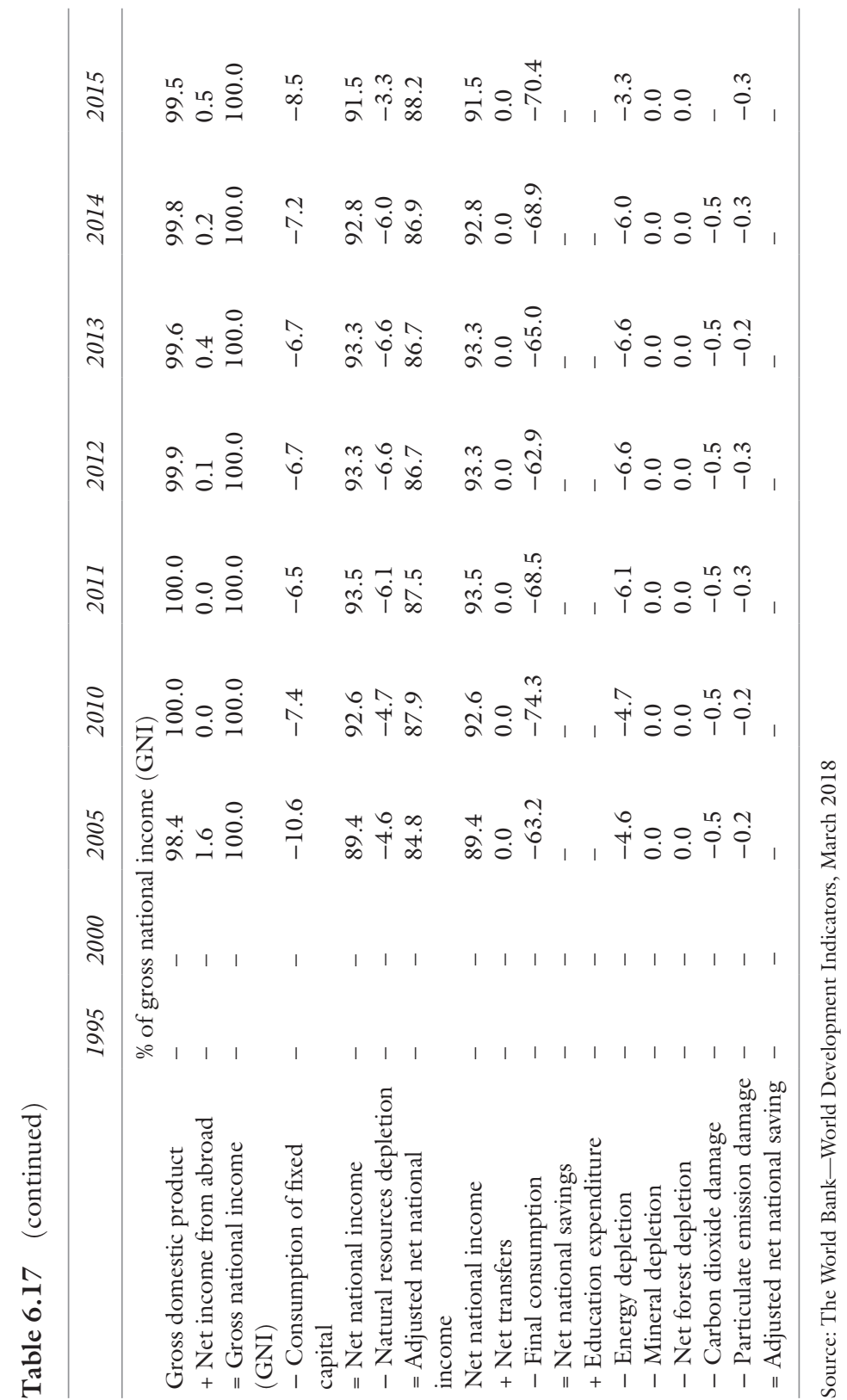


consumption ratios in recent years. Due to substantial net income from abroad, GNI is larger than GDP throughout the whole period.

Is Oman the problem-child of the GCC at present? Oman is the only GCC country for which the test for sustainable development failed. The adjusted net savings ratio in the last row of Table 6.14 is negative throughout the period due to heavy allocation for energy depletion and negative income from abroad. As a consequence, it must be expected that the combined capital stock of man-made capital and natural capital declined.

The test for sustainable development of Qatar in Table 6.15 shows favourable results. In 2014, the share of adjusted net savings in GNI is $41.7 \%$ despite negative income from abroad. The allocations for natural resources depletion are relatively modest and the share of consumption in GNI very low.

In Table 6.16, the test of sustainable development is applied to Saudi Arabia. Saudi Arabia has significant net incomes from abroad, low allocations for consumption of fixed capital, moderate allocation for natural resource depletion and the highest allocations for education expenditures of the GCC countries. Since 2005, adjusted net savings are in the range of 20-30 per cent of GNI. This level is an achievement as it even exceeded the corresponding level of Norway.

Table 6.17 includes the test for sustainable development of the United Arab Emirates. Unfortunately, no information is available on net transfers and education expenditure. Therefore, no estimate on net savings and net adjusted savings is available. However, the information on energy depletion allows assessing the adjusted net national income. The reported shares of energy depletion in GNI are low compared to other GCC countries.

In 2006, the World Bank published the Little Green Data Book 2006 (World Bank 2006). In this assessment, energy depletion is equal to the product of unit resource rents and the physical quantities of energy extracted. It should be noted that a recent change in methodology in the new time series of the World Bank's World Development Indicators now estimates energy depletion as the ratio of the value of the stock of energy resources to the remaining reserve lifetime (capped at 25 years), covering coal, crude oil and natural gas. The new results for 2005 are quite different from the previous ones in the Little Green Data Book 2006 for the GCC countries. The significant revision of the methodology to estimate the depletion of natural resources brought about a sudden, and debatable, improvement in the estimate of adjusted savings for the GCC. 


\section{Conclusion}

This article has argued that, perhaps contrary to established opinion, the economic diversification of GCC countries is well underway. In many ways, the GCC countries are approaching the diversification levels of the reference country Norway. The test for sustainable development of GCC countries for the period 1995-2015 showed positive results for most years. In 2014, Qatar and Kuwait achieved high rates of adjusted net national saving per person; Qatar even surpassed the level of Norway. Bahrain and Saudi Arabia realised small positive rates. Oman was the only GCC country for which the test yielded a negative result. During the last 20 years (1995-2015), Bahrain, Kuwait, Qatar and Saudi Arabia had positive rates of adjusted net saving throughout the whole period, whereas for Oman the rate was only positive in 2012 .

A full implementation of the input-output approach will only be possible if supply and use tables become available for all GCC countries, which are comparable, have the same number of products and industries and use the same classification of the System of National Accounts 2008SNA 2008 (United Nations 2009). At the moment, only selected inputoutput tables are available for Kuwait and Saudi Arabia. The National Statistical Offices of the GCC countries should be encouraged to compile annual supply and use tables as an integral part of their national accounts, which are in line with the SNA 2008.

\section{REFERENCES}

Al-Kawaz, Ahmed (2008): Economic Diversification: The Case of Kuwait with Reference to Oil Producing Countries, Journal of Economic Cooperation, 29, pp. 23-48.

Beutel, Joerg (2012): Conceptual Problems of Measuring Economic Diversification as Applied to the GCC Countries, in: Giacomo Luciani (ed.), Resources Blessed: Diversification and the Gulf Development Model, Gulf Research Centre, Gerlach Press, pp. 29-70.

Beutel, Joerg, Isabelle Rémond-Tiedrez, José M. Rueda Cantuche (2013): The Importance of Input-Output Data for the Regional Integration and Sustainable Development of the European Union, in Joy Murray and Manfred Lenzen (eds.), The Sustainability Practitioner's Guide to Multi-Regional Input-Output Analysis, Champaign, IL, USA, pp. 220-239.

Beutel, Joerg (2017): The supply and use framework of national accounts, in: Thijs ten Raa (ed.): Handbook of Input-Output Analysis, Cheltenham, UK, pp. 41-129. 
Green, David (2011). Input-Output Table for Kuwait 2005, GTAP-Global Trade Analysis Project, Center for Global Trade Analysis, Purdue University, Indiana. OECD (2018): Harmonised National Input-Output Tables.

United Nations (2009): System of National Accounts 2008.

United Nations (2018): Handbook on Supply, Use and Input-Output Tables with Extensions and Applications.

Wagner, John E.; Steven C. Deller (1998): Measuring the Effects of Economic Diversity on Growth and Stability, Land Economics, Vol. 74, No. 4, pp. 541-556.

World Bank (2001): The Changing Wealth of Nations: Measuring Sustainable Development in the New Millennium.

World Bank (2006): Little Green Data Book 2006, Washington DC.

World Bank (2018): World Development Indicators, Washington, DC.

Open Access This chapter is licensed under the terms of the Creative Commons Attribution-NonCommercial-NoDerivatives 4.0 International License (http:// creativecommons.org/licenses/by-nc-nd/4.0/), which permits any noncommercial use, sharing, distribution and reproduction in any medium or format, as long as you give appropriate credit to the original author(s) and the source, provide a link to the Creative Commons licence and indicate if you modified the licensed material. You do not have permission under this licence to share adapted material derived from this chapter or parts of it.

The images or other third party material in this chapter are included in the chapter's Creative Commons licence, unless indicated otherwise in a credit line to the material. If material is not included in the chapter's Creative Commons licence and your intended use is not permitted by statutory regulation or exceeds the permitted use, you will need to obtain permission directly from the copyright holder. 